\title{
Review \\ Sustainability Recommendations and Practices in School Feeding: A Systematic Review
}

\author{
Emanuele Batistela dos Santos ${ }^{1}$, Dayanne da Costa Maynard ${ }^{2}(D)$, Renata Puppin Zandonadi ${ }^{2}(D$, \\ António Raposo ${ }^{3, *(\mathbb{D})}$ and Raquel Braz Assunção Botelho 1,*(i)
}

check for

updates

Citation: dos Santos, E.B.; da Costa Maynard, D.; Zandonadi, R.P.; Raposo, A.; Botelho, R.B.A. Sustainability Recommendations and Practices in School Feeding: A Systematic Review. Foods 2022, 11, 176. https://doi.org/10.3390/ foods11020176

Academic Editor: Theodoros Varzakas

Received: 8 December 2021 Accepted: 4 January 2022

Published: 10 January 2022

Publisher's Note: MDPI stays neutral with regard to jurisdictional claims in published maps and institutional affiliations.

Copyright: (C) 2022 by the authors. Licensee MDPI, Basel, Switzerland. This article is an open access article distributed under the terms and conditions of the Creative Commons Attribution (CC BY) license (https:// creativecommons.org/licenses/by/ $4.0 /)$.
1 Department of Food and Nutrition, Federal University of Mato Grosso, Cuiabá 78060-900, Brazil; emanuelebatistela.ufmt@gmail.com

2 Department of Nutrition, University of Brasília, Brasília 70910-900,Brazil; day_nut@yahoo.com.br (D.d.C.M.); renatapz@unb.br (R.P.Z.)

3 CBIOS (Research Center for Biosciences and Health Technologies), Universidade Lusófona de Humanidades e Tecnologias, Campo Grande 376, 1749-024 Lisboa, Portugal

* Correspondence: antonio.raposo@ulusofona.pt (A.R.); raquelbotelho@unb.br (R.B.A.B.)

\begin{abstract}
Considering the importance of schools for sustainable food offers and the formation of conscientious citizens on sustainability, this systematic review aimed to verify the recommendations on sustainability in school feeding policies and the sustainability practices adopted in schools. The research question that guided this study is "what are the recommendations on sustainability in school feeding policies and the sustainability practices adopted in schools?". This systematic review was prepared according to PRISMA, and its checklist was registered in PROSPERO. Specific search strategies for Scopus, Web of Science, Pubmed, Lilacs, Google Scholar, and ProQuest Dissertations \& Theses Global were developed. The included studies' methodological quality was evaluated using the Meta-Analysis Statistical Assessment and Review Instrument (MASTARI). A total of 134 studies were selected for a full reading. Of these, 50 met the eligibility criteria and were included in the systematic review. Several sustainability practices were described. The most cited are school gardens and education activities for sustainability. However, actions carried out in food services were also mentioned, from the planning of menus and the purchase of raw materials (mainly local and organic foods, vegetarian/vegan menus) to the distribution of meals (reduction of organic and inorganic waste: composting, recycling, donating food, and portion sizes). Recommendations for purchasing sustainable food (organic, local, and seasonal), nutrition education focused on sustainability, and reducing food waste were frequent; this reinforces the need to stimulate managers' view, in their most varied spheres, for the priority that should be given to this theme, so that education for sustainability is universally part of the curricula. The importance of education in enabling individuals to promote sustainable development is reaffirmed in Sustainable Development Goal 4 (SDG 4). The development of assessment instruments can help monitor the evolution of sustainable strategies at schools and the main barriers and potentialities related to their implementation.
\end{abstract}

Keywords: school feeding; school meals; sustainability

\section{Introduction}

School feeding programs, widely spread across the globe, are recognized as an essential strategy for achieving goals in various sectors of society, including education, health, social protection, and agriculture. Recognized as the most prominent social protection network globally, even with the effects suffered by the COVID-19 pandemic, they appear as a robust investment in human capital that will guarantee the economic growth of nations [1]. The relationship between school feeding and educational and nutritional outcomes is widely investigated in the literature [2-5]. However, more recently, its role in conducting actions aimed at sustainability has been studied to mitigate the global challenges that threaten human and planet health in the 21st century [6-8]. 
A product of the concern with the environmental impacts derived from the world pattern of production and consumption in the second half of the 20th century, the term sustainable development refers to satisfying the needs of the present without compromising the ability of future generations to meet their own needs [9]. Integrating the sustainability pillars is necessary to increase productive potential, guaranteeing equal opportunities for all without putting the environment at risk [10]. The three main pillars (environmental, economic, and social) have been studied for years, and, recently, the cultural and health pillars were also linked to sustainability [11].

Through school meals and educational practices, students become aware of the impacts of individual and collective choices [6,12-14], consequently generating better environmental, economic, and social outcomes. The essential role of education for achieving a more sustainable future in environmental, economic, and social aspects was recognized by the United Nations in the Decade of Education for Sustainable Development, which aimed to integrate the values, principles, and practices of sustainable development in all aspects of education [15]. Therefore, education for sustainability is a powerful tool capable of providing the knowledge, skills, and awareness needed by young people to deal with the various problems that threaten the integrity of the planet and human health and well-being [16]. In this sense, it is essential to conduct a process that considers, in addition to global issues, those that are local and common to the participants' routine and that integrates a holistic perspective, allowing for informed decision-making, individually or collectively $[15,17]$. The literature also highlights the importance of using school meals as a tool for nutritional education and education for sustainable consumption and practical learning activities, such as school gardens, cooking activities, and field visits to small local farmers [6,12,18-20].

The relationship between sustainability and school feeding also occurs at the level of decisions made at all stages of meal production. It is known that food production is associated with significant environmental impacts. Although elements before or after the meals' preparation are responsible for most of these effects (such as field production, transport, and food waste) [21-23], the choices made by school food services influence this dynamic, determining the degree to which they employ actions to mitigate the environmental impacts generated in this process. Some examples are the purchase of organic and local food, encouraging the consumption of fresh vegetables at meals, controlling the supply of meat, and actions such as adjusting portions, donating food, composting, purchasing products with minimum packaging, recycling, and reducing energy and water consumption [24-30].

The adoption of sustainable practices often generates results that simultaneously reach the different dimensions of sustainability. Reducing energy and water consumption in the production of meals and adjusting the size of food portions, for example, can represent actions of economic and environmental sustainability [29]. Also, the donation of food, raw or prepared, provided that it is in perfect hygienic and sanitary condition, can be observed from social and environmental sustainability perspectives [26,27].

Establishing a close relationship between school meals and small farmers to purchase locally sourced food favors the increase in income and class organization. Consequently, the economic development of the region, as well as contributing to the food and nutritional security of farmers and their families [31,32], goes beyond environmental to social and economic sustainability dimensions. Due to the benefits for both students and farmers widely recognized in the literature, the practice of buying local food is encouraged by public policies for school meals in different parts of the world [33,34].

Therefore, the range of activities involved with school feeding generates unique challenges and opportunities from the point of view of sustainability in the environmental, economic, and social dimensions $[7,8,12,35]$. In this sense, school feeding programs are part of the strategies used to achieve the Sustainable Development Goals of the 2030 Agenda [36].

Although school feeding policies in some countries already present recommendations on sustainability in their guiding principles $[34,37,38]$, and the literature presents different sustainability practices employed in this context, bringing to light a body of evidence on 
this topic will be helpful for decision-makers at the government level to create or even revise guidelines for their school feeding policies, incorporating the principles of sustainability. Therefore, the research question that guided this study is "What are the recommendations on sustainability in school feeding policies and the sustainability practices adopted in schools?". In addition, the findings may help policymakers and members of the school community, within their local context, in the development of sustainability practices linked to school and school feeding. Considering the importance of schools to offer sustainable food and in the formation of conscientious citizens who are able to act on the challenges related to sustainability in the contemporary world [6], this systematic review aimed to verify the recommendations on sustainability in school feeding policies and the sustainability practices adopted in schools.

\section{Materials and Methods}

This systematic review was prepared according to the Preferred Reporting Items for Systematic Reviews and Meta-Analyses (PRISMA), and its checklist [39] was registered in PROSPERO [CRD42021264978]. The protocol was performed according to the following steps.

\subsection{Inclusion and Exclusion Criteria}

The inclusion criteria were studies that described the recommendations on sustainability in school feeding policies and the sustainability practices adopted in schools, in environmental, social, and/or economic aspects, with no date and language limits. Legislations of school feeding policies and programs found in the studies reference lists had their full text analyzed to identify sustainability recommendations. The exclusion criteria were: (1) comments, letters, conferences, reviews, abstracts, reports, undergraduate works, discussion papers, and books, (2) studies carried out outside schools or in which the school was not responsible for the action, (3) studies in which practices were not performed or studies where activities were punctual, (4) studies focused on the supplier or that only reported purchases, and (5) studies that did not describe sustainability practices (Appendix A).

\subsection{Information Source}

Detailed individual search strategies were developed for each database: MEDLINE via Pubmed, Embase, Scopus, Web of Science, and Lilacs. A search for gray literature was performed on Google Scholar and for dissertations and theses in ProQuest Global. Additionally, we examined the reference lists of the selected articles as relevant studies could have been missed during the data search. The last search in all databases was carried out on 30 June 2021.

\subsection{Search Strategy}

The appropriate combinations of truncation and keywords were selected and adapted for the search in each mentioned database (Table S1-Supplementary Materials). We used Rayyan software (Qatar Computer Research Institute (QCRI)) to select and exclude duplicate articles, and all references were managed by Mendeley desktop software.

\subsection{Study Selection}

Two phases were necessary for the selection. In phase 1, researchers I (EBS) and II (DCM) independently reviewed the titles and abstracts of all references identified from databases. EBS and DCM excluded the articles that did not meet the eligibility criteria. In phase 2, the full texts of the selected articles were fully read by the same reviewers (EBS, DCM), and only those that met the inclusion criteria were included. In both phases, the disagreements were discussed until a consensus was reached between the two reviewers. A third reviewer (RBAB) made the final decision in situations without consensus. EBS, an examiner, critically evaluated the list of references of the selected studies. Additional studies were added by the third examiner (RBAB) and the expert (RPZ). 


\subsection{Data Collection Process}

Two reviewers independently (EBS, DCM) collected the following characteristics from the selected studies by authors and year of publication, country of research, the objective of the study, methods, sustainability dimensions, and main results referring to the identified sustainability practices. Calibration exercises were conducted before starting the review to ensure consistency among reviewers. Disagreements were solved by discussion, and the third reviewer (RBAB) adjudicated unresolved disagreements. These data were synthesized by three reviewers (EBS, DCM, and RBAB) using a standardized table containing the following information: reference, authors, year, country, objectives, type of school management (public, private), teaching stage (according to the teaching stages of each country), participants (individuals, schools, or municipalities), sustainability dimensions (environmental, economic, and social), and main results referring to the identified sustainability practices.

\subsection{Risk of Individual Bias in the Included Studies}

The quality criteria were synthesized using a statistical review assessment instrument (MASTARI) and the Joanna Briggs Institute protocol to assess the risk of bias in the studies. The instrument for assessing the risk of bias included seven questions:

1. Were the practices identified characterized?

2. Has the practice been implemented in schools?

3. Did the practices present a positive implementation response?

4. Was the study design appropriate?

5. Was the statistical analysis adequate to the objective of the study?

6. Did the results answer the main question?

7. In the case of the schools, was the sample of establishments selected for analysis representative and randomly determined?

The categorization of the risk of bias followed the percentage of "yes" score: "High" for up to $49 \%$, "Moderate" for between 50 and $69 \%$, and "Low" for more than $70 \%$.

\section{Results}

The researchers retrieved 1763 studies from the electronic databases; 1319 titles and abstracts were evaluated after removing the duplicates, and, after reading the abstracts, 134 studies were selected for a full reading. Of these, 50 met the eligibility criteria and were included in the systematic review. At the same time, recommendations on sustainability were found in 11 governmental school feeding policies or programs and 5 in other available non-governmental school feeding programs/initiatives retrieved from the studies' reference lists (Figure 1). The latest available versions were evaluated for governmental and nongovernmental school feeding policies or programs.

\subsection{Studies Characteristics}

Regarding sustainability practices, the studies included $(n=50)$ were conducted between 1991 and 2021, in the following countries: United States $(n=22)$, Brazil $(n=7)$, Spain $(n=3)$, Italy $(n=3)$, South Africa $(n=2)$, Canada $(n=2)$, England $(n=2)$, Denmark $(n=1)$, Finland $(n=1)$, Ghana $(n=1)$, India $(n=1)$, Japan $(n=1)$, Wales $(n=1)$, Kenya $(n=1)$, and Tanzania $(n=1)$. A parallel study was carried out in the United States and Cuba. The characteristics of the analyzed studies are presented in Table 1. 
Identification of studies via databases and registers

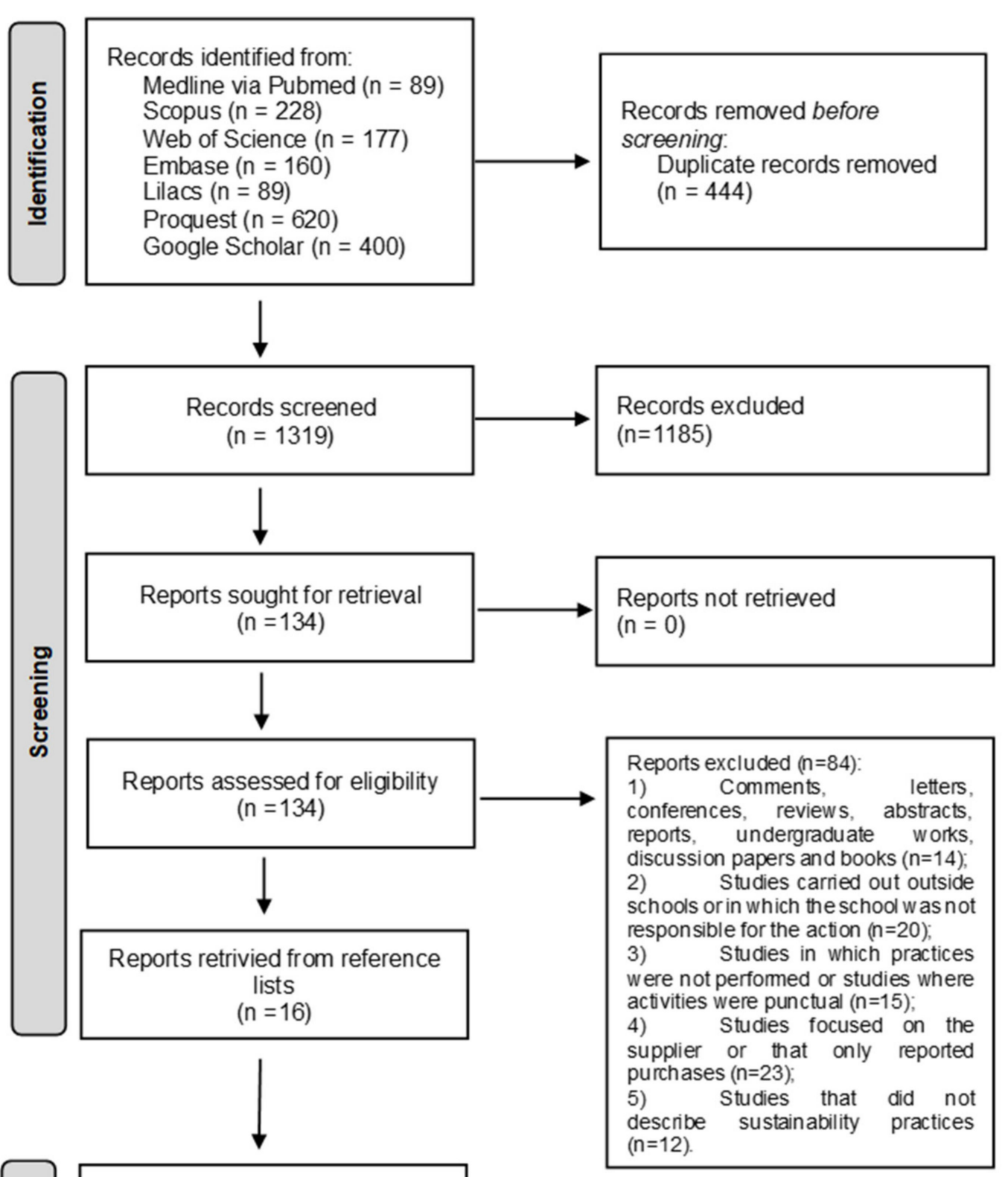

Studies included in review $(n=66)$

Figure 1. Flowchart of the systematic review search process. Adapted from PRISMA protocol. 
Table 1. Main descriptive characteristics and results from the included studies.

\begin{tabular}{|c|c|c|c|}
\hline $\begin{array}{l}\text { Author } \\
\text { (Year) } \\
\text { Country }\end{array}$ & Objectives & $\begin{array}{c}\text { School Management (SM) } \\
\text { Teaching Stage (TS) } \\
\text { Participants (P) } \\
\text { Sustainability Dimension (SD) }\end{array}$ & Main Sustainability Practices Identified \\
\hline $\begin{array}{l}\text { Mann } \\
(1991)[40] \\
\text { USA }\end{array}$ & $\begin{array}{l}\text { To assess the solid waste management practices in } \\
\text { school food, and to develop and assess a decision } \\
\text { model for solid waste management in school } \\
\text { food services. }\end{array}$ & $\begin{array}{c}\text { SM: Public, private } \\
\text { TS: Not informed } \\
\text { P: School food service directors }(n=458) \\
\text { SD: Environmental, economic }\end{array}$ & $\begin{array}{l}\text { Recycling, purchase of bulk products, and } \\
\text { reusable dispensing devices. }\end{array}$ \\
\hline $\begin{array}{l}\text { Ghiselli } \\
(1993)[41] \\
\text { USA }\end{array}$ & $\begin{array}{l}\text { To analyze waste and disposal practices in Indiana's } \\
\text { school food service, and the feasibility of reducing it } \\
\text { through permanent service and product recycling. }\end{array}$ & $\begin{array}{c}\text { SM: Public, private } \\
\text { TS: Elementary, middle, high school } \\
\text { P: School food service directors }(n=237) \\
\text { SD: Environmental, economic }\end{array}$ & Recycling. \\
\hline $\begin{array}{l}\text { Hackes; Shanklin } \\
\text { (1999) [42] } \\
\text { USA }\end{array}$ & $\begin{array}{l}\text { To identify resource allocation decisions, policies, and } \\
\text { procedures used by school food service directors that } \\
\text { were based on pollution prevention, product } \\
\text { stewardship, and sustainable development. }\end{array}$ & $\begin{array}{c}\text { SM: Not informed } \\
\text { TS: Not informed } \\
\text { P: School food service directors }(n=168) \\
\text { SD: Environmental, economic }\end{array}$ & $\begin{array}{l}\text { Recycling; energy policy: solid waste } \\
\text { and water. }\end{array}$ \\
\hline $\begin{array}{l}\text { Albertse, Mancusi-Materi (2000) [43] } \\
\text { South Africa }\end{array}$ & $\begin{array}{l}\text { To illustrate how the initiation of school children into } \\
\text { innovative technologies has fostered mechanisms of } \\
\text { social mobilization towards enhanced food security } \\
\text { in South Africa. }\end{array}$ & $\begin{array}{c}\text { SM: Not informed } \\
\text { TS: Not informed } \\
\text { P: Students, parents }(n=\text { not informed }) \\
\text { SD: Environmental, economic, social }\end{array}$ & $\begin{array}{l}\text { Irrigation system for water reuse and } \\
\text { school garden. }\end{array}$ \\
\hline $\begin{array}{l}\text { Wadsworth } \\
\text { (2002) [44] } \\
\text { USA }\end{array}$ & $\begin{array}{l}\text { To conduct a curriculum assessment of an after-school } \\
\text { program on food choices that minimize energy, } \\
\text { natural resources used, and pollution generated in } \\
\text { food processing, packaging, and transportation. }\end{array}$ & $\begin{array}{c}\text { SM: Public } \\
\text { TS: Elementary } \\
\text { P: Students }(n=240) \\
\text { SD: Environmental }\end{array}$ & $\begin{array}{l}\text { Nutritional education focused on the } \\
\text { sustainability of the food system; } \\
\text { Cooking activities. }\end{array}$ \\
\hline $\begin{array}{l}\text { Lima } \\
(2006)[45] \\
\text { Brazil }\end{array}$ & $\begin{array}{l}\text { To analyze the management of a School food service } \\
\text { unit in the State of Santa Catarina, based on the } \\
\text { introduction of organic foods. }\end{array}$ & $\begin{array}{c}\text { SM: Public } \\
\text { TS: Elementary } \\
\text { P: Representatives of the Department of } \\
\text { Education, a state school, the School Feeding } \\
\text { Council, students }(n=21) \\
\text { SD: Environmental }\end{array}$ & $\begin{array}{l}\text { Organic school garden and feeding program; } \\
\text { Control of non-organic waste generation. }\end{array}$ \\
\hline $\begin{array}{l}\text { Vogt } \\
(2006)[46] \\
\text { USA }\end{array}$ & $\begin{array}{l}\text { To identify district/community characteristics } \\
\text { supporting buying food locally, the perceived benefits } \\
\text { and barriers in buying locally, and generate solutions } \\
\text { to encountered issues in California. }\end{array}$ & $\begin{array}{c}\text { SM: Public } \\
\text { TS: Not informed } \\
\text { P: School food service directors, farmers }(n=37) \\
\text { SD: Environmental, economic, social }\end{array}$ & $\begin{array}{l}\text { Participation in the "Farm-to-School" } \\
\text { program (local foods), school garden, } \\
\text { recycling, composting, and } \\
\text { vegetarian/vegan meals. }\end{array}$ \\
\hline
\end{tabular}


Table 1. Cont.

\begin{tabular}{|c|c|c|c|}
\hline $\begin{array}{l}\text { Author } \\
\text { (Year) } \\
\text { Country }\end{array}$ & Objectives & $\begin{array}{c}\text { School Management (SM) } \\
\text { Teaching Stage (TS) } \\
\text { Participants (P) } \\
\text { Sustainability Dimension (SD) }\end{array}$ & Main Sustainability Practices Identified \\
\hline $\begin{array}{l}\text { Sonnino } \\
(2009)[47] \\
\quad \text { Italy }\end{array}$ & $\begin{array}{l}\text { To examine how city authorities have integrated } \\
\text { different (and at times contrasting) quality } \\
\text { conventions in school meals in Rome. }\end{array}$ & $\begin{array}{c}\text { SM: Public } \\
\text { TS: Not informed } \\
\text { P: Representatives of the sectors involved in } \\
\text { school feeding }(n=\text { not informed) } \\
\text { SD: Environmental, economic, social }\end{array}$ & $\begin{array}{l}\text { Purchase of organic food; Adoption of social } \\
\text { and environmental criteria for contracting } \\
\text { food services. }\end{array}$ \\
\hline $\begin{array}{l}\text { Baca } \\
(2011)[49] \\
\text { USA }\end{array}$ & $\begin{array}{l}\text { To investigate the status of food waste management } \\
\text { programs, recycling of packaging waste, and cost of } \\
\text { waste hauling in school nutrition programs } \\
\text { in the USA. }\end{array}$ & $\begin{array}{c}\text { SM: Not informed } \\
\text { TS: Not informed } \\
\text { P: Child nutrition directors }(n=79) \\
\text { SD: Environmental, economic, social }\end{array}$ & $\begin{array}{l}\text { Food donation, composting, donation of } \\
\text { waste for animal feed, recycling. }\end{array}$ \\
\hline $\begin{array}{l}\text { Bucher } \\
(2012)[51] \\
\text { USA/Cuba }\end{array}$ & $\begin{array}{c}\text { To examine how pedagogies of sustainability are } \\
\text { embedded in socio-cultural contexts and policy } \\
\text { structures and driven by the localized actions } \\
\text { of teachers. }\end{array}$ & $\begin{array}{c}\text { SM: Public } \\
\text { TS: Elementary, primary, } \\
\text { high school } \\
\text { P: Teachers, community members }(n=12) \\
\text { SD: Environmental, social }\end{array}$ & Environmental education; school garden. \\
\hline $\begin{array}{l}\text { Jones et al. } \\
\text { (2012) [12] } \\
\text { England }\end{array}$ & $\begin{array}{l}\text { To examine the associations between the promotion } \\
\text { of sustainable food and student self-reported fruit } \\
\text { and vegetable consumption and associated behaviors. }\end{array}$ & $\begin{array}{l}\text { SM: Not informed } \\
\text { TS: Elementary } \\
\text { P: Students }(n=1435) \\
\text { SD: Environmental }\end{array}$ & $\begin{array}{l}\text { Participation in a sustainable food program } \\
\text { (education for sustainability, use of } \\
\text { sustainable food). }\end{array}$ \\
\hline
\end{tabular}


Table 1. Cont.

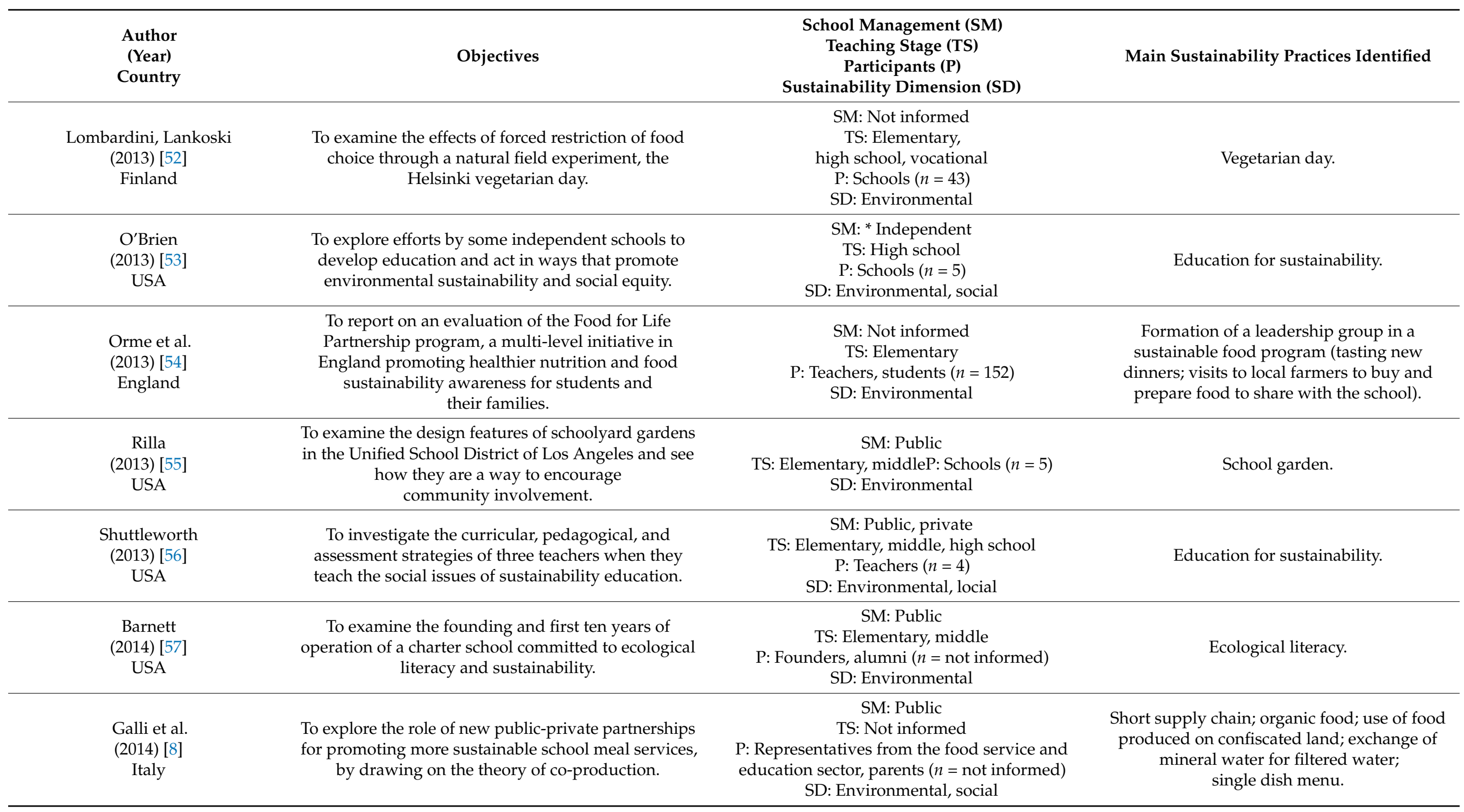


Table 1. Cont.

\begin{tabular}{|c|c|c|c|}
\hline $\begin{array}{l}\text { Author } \\
\text { (Year) } \\
\text { Country }\end{array}$ & Objectives & $\begin{array}{c}\text { School Management (SM) } \\
\text { Teaching Stage (TS) } \\
\text { Participants (P) } \\
\text { Sustainability Dimension (SD) }\end{array}$ & Main Sustainability Practices Identified \\
\hline $\begin{array}{l}\text { He, Mikkelsen } \\
\text { (2014) [58] } \\
\text { Denmark }\end{array}$ & $\begin{array}{l}\text { To examine the possible influence of organic food } \\
\text { policies on Danish school feeding systems on the } \\
\text { development of healthier school food environments. }\end{array}$ & $\begin{array}{c}\text { SM: Public } \\
\text { TS: Elementary } \\
\text { P: School food service supervisors }(n=92) \\
\text { SD: Environmental }\end{array}$ & Organic food. \\
\hline $\begin{array}{l}\text { Keller } \\
(2014)[59] \\
\text { USA }\end{array}$ & $\begin{array}{c}\text { To examine how educators are fostering sustainability } \\
\text { through cultivating nature awareness in } \\
\text { young children. }\end{array}$ & $\begin{array}{c}\text { SM: Public, independent } \\
\text { TS: Elementary } \\
\text { P: Scholar, education director, teachers, principal } \\
\quad(n=6) \\
\text { SD: Environmental, } \\
\text { economic, social }\end{array}$ & $\begin{array}{l}\text { Ecological literacy; school garden; field trips } \\
\text { to farmers; local and organic foods. }\end{array}$ \\
\hline $\begin{array}{l}\text { Bamford } \\
(2015)[60] \\
\text { USA }\end{array}$ & $\begin{array}{l}\text { To discover the relationships between educational } \\
\text { experience and sustainability attitudes and behaviors, } \\
\text { the motivation behind these behaviors, and establish } \\
\text { their role in educational programs. }\end{array}$ & $\begin{array}{c}\text { SM: Not informed } \\
\text { TS: Elementary } \\
\text { P: Students, teachers }(n=102) \\
\text { SD: Environmental, social }\end{array}$ & $\begin{array}{l}\text { Sustainability curriculum; school garden; } \\
\text { field trips. }\end{array}$ \\
\hline $\begin{array}{l}\text { Coe } \\
\text { (2015) [61] } \\
\text { USA }\end{array}$ & $\begin{array}{c}\text { To understand how a school gardening program and } \\
\text { its ecology curriculum influences students' } \\
\text { environmental perceptions } \\
\text { and attitudes. }\end{array}$ & $\begin{array}{c}\text { SM: Public } \\
\text { TS: Elementary } \\
\text { P: Students }(n=21) \text {, parents }(n=3) \text {, staff }(n=3) \\
\text { SD: Environmental }\end{array}$ & $\begin{array}{l}\text { Ecology curriculum; organic school garden; } \\
\text { rainwater collection cistern; composting. }\end{array}$ \\
\hline $\begin{array}{l}\text { Fabri et al. } \\
(2015)[62] \\
\text { Brazil }\end{array}$ & $\begin{array}{l}\text { To identify and analyze the use of regional foods in } \\
\text { the school meals of a Brazilian city. }\end{array}$ & $\begin{array}{c}\text { SM: Public } \\
\text { TS: Not informed } \\
\text { P: City }(n=1) \\
\text { SD: Environmental, economic, social }\end{array}$ & Regional food. \\
\hline
\end{tabular}


Table 1. Cont.

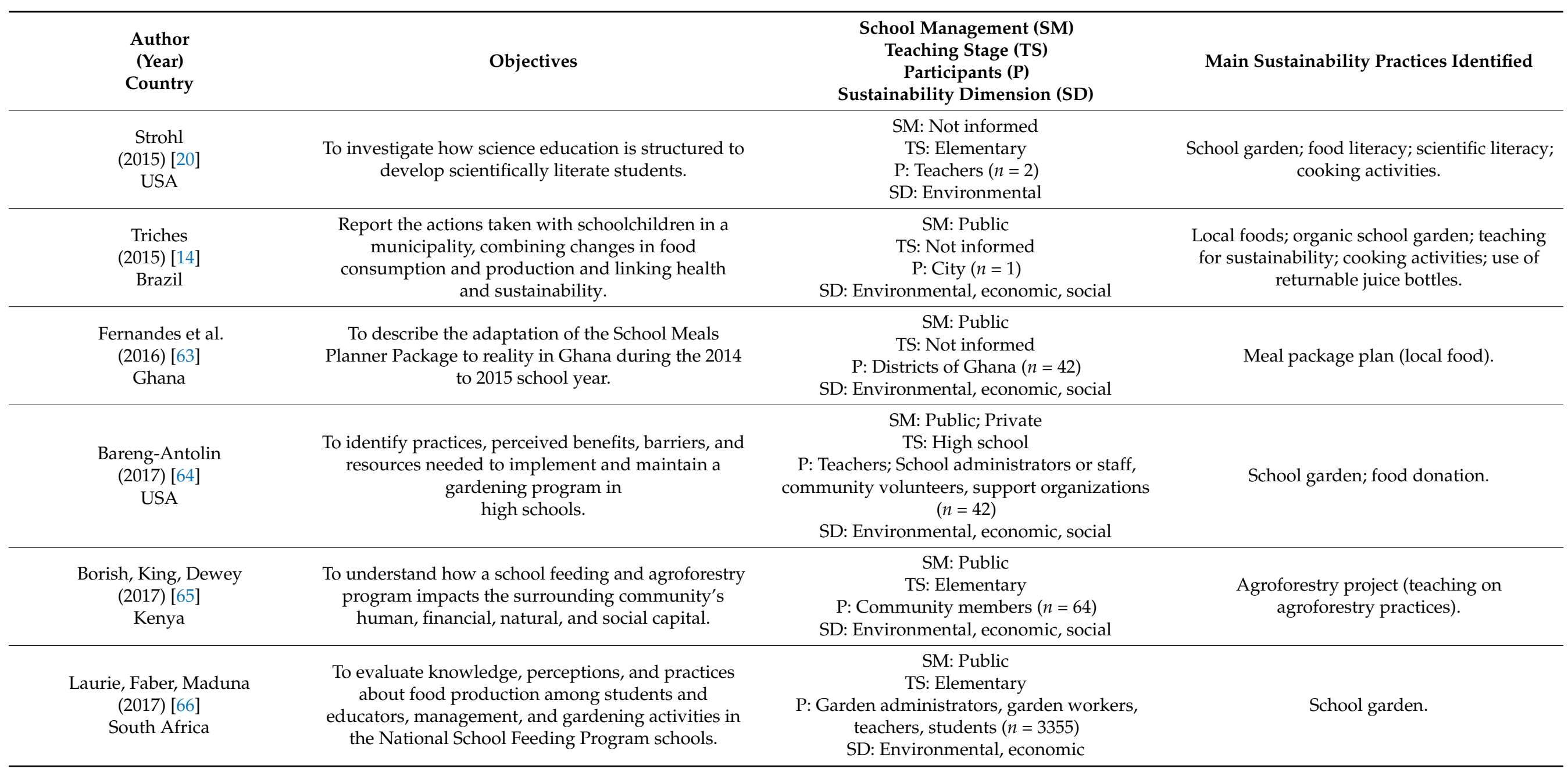


Table 1. Cont.

\begin{tabular}{|c|c|c|c|}
\hline $\begin{array}{l}\text { Author } \\
\text { (Year) } \\
\text { Country }\end{array}$ & Objectives & $\begin{array}{c}\text { School Management (SM) } \\
\text { Teaching Stage (TS) } \\
\text { Participants (P) } \\
\text { Sustainability Dimension (SD) }\end{array}$ & Main Sustainability Practices Identified \\
\hline $\begin{array}{l}\text { Soares et al. } \\
(2017) \text { [67] } \\
\text { Spain }\end{array}$ & $\begin{array}{l}\text { To identify and characterize initiatives that promote } \\
\text { the purchase of locally-sourced foods to supply } \\
\text { schools and the schools carrying out the initiatives. }\end{array}$ & $\begin{array}{c}\text { SM: Public, private } \\
\text { TS: Kindergarten, elementary, high school, } \\
\text { special school } \\
\text { P: Informants from the Ministries of Education } \\
\text { and Agriculture }(n=\text { Not informed }) \\
\text { SD: Environmental, economic, social }\end{array}$ & Local foods; organic food. \\
\hline $\begin{array}{l}\text { Garcia } \\
(2018)[68] \\
\text { Brazil }\end{array}$ & $\begin{array}{l}\text { To analyze the actions of the National School Feeding } \\
\text { Program in the city of Marechal Cândido Rondon-PR. }\end{array}$ & $\begin{array}{c}\text { SM: Public } \\
\text { TS: Kindergarten, elementary, high school, } \\
\text { special school } \\
\text { P: Family farmers, nutritionists, managers, cooks, } \\
\text { teachers }(n=125) \\
\text { SD: Environmental, economic, social }\end{array}$ & $\begin{array}{l}\text { Sustainability training; partnerships for } \\
\text { environmental preservation, short circuit } \\
\text { sales, and certification of organic food; } \\
\text { competition and recipe booklet for the use of } \\
\text { organic products and valorization of work. }\end{array}$ \\
\hline $\begin{array}{l}\text { Huston } \\
\text { (2018) [69] } \\
\text { USA }\end{array}$ & $\begin{array}{l}\text { To highlight how leadership affects the } \\
\text { implementation of education forsustainability in two } \\
\text { K-6 elementary schools in rural } \\
\text { New England. }\end{array}$ & $\begin{array}{c}\text { SM: Public } \\
\text { TS: Elementary } \\
\text { P: School staff members }(n=23) \\
\text { SD: Environmental, economic, social }\end{array}$ & $\begin{array}{l}\text { Education for sustainability; participation in } \\
\text { the "Farm-to-School" program; student } \\
\text { participation in the local food pantry. }\end{array}$ \\
\hline $\begin{array}{l}\text { Lagorio et al. } \\
\text { (2018) [27] } \\
\text { Italy }\end{array}$ & $\begin{array}{l}\text { To use a case study in Italy to illustrate an effective } \\
\text { and reliable strategy to reduce food waste in public } \\
\text { school canteens. }\end{array}$ & $\begin{array}{c}\text { SM: Public } \\
\text { TS: Elementary, high school } \\
\text { P: Municipal Councillors of Social Policies and of } \\
\text { Education }(n=2) \\
\text { SD: Environmental, social }\end{array}$ & $\begin{array}{l}\text { Portion adequacy; } \\
\text { food donation. }\end{array}$ \\
\hline $\begin{array}{l}\text { Lehnerd } \\
(2018)[70] \\
\text { USA }\end{array}$ & $\begin{array}{l}\text { To investigate the adoption and the potential impacts } \\
\text { of the Farmers' Market Nutrition Incentive and Farm } \\
\text { to School programs. }\end{array}$ & $\begin{array}{c}\text { SM: Not informed } \\
\text { TS: Elementary, middle } \\
\text { P: Farmer, food service administrators or } \\
\text { principals, students }(n=721) \\
\text { SD: Environmental, economic, social }\end{array}$ & $\begin{array}{l}\text { Participation in the "Farm to School" program } \\
\text { (school garden; local foods) }\end{array}$ \\
\hline
\end{tabular}


Table 1. Cont.

\begin{tabular}{|c|c|c|c|}
\hline $\begin{array}{l}\text { Author } \\
\text { (Year) } \\
\text { Country }\end{array}$ & Objectives & $\begin{array}{c}\text { School Management (SM) } \\
\text { Teaching Stage (TS) } \\
\text { Participants (P) } \\
\text { Sustainability Dimension (SD) }\end{array}$ & Main Sustainability Practices Identified \\
\hline $\begin{array}{l}\text { Powell, Wittman } \\
\text { (2018) [71] } \\
\text { Canada }\end{array}$ & $\begin{array}{l}\text { To investigate the farm-to-school movement in British } \\
\text { Columbia, where concerns related to education and } \\
\text { health have been the main vectors of farm-to-school } \\
\text { mobilization. }\end{array}$ & $\begin{array}{c}\text { SM: Public } \\
\text { TS: Not informed } \\
\text { P: Farm-to-school actors }(n=30) \\
\text { SD: Environmental, economic, social }\end{array}$ & $\begin{array}{c}\text { Participation in the "Farm-to-School" } \\
\text { program (local food, food literacy, school } \\
\text { garden). }\end{array}$ \\
\hline $\begin{array}{l}\text { Roy et al. } \\
\text { (2018) [72] } \\
\text { India }\end{array}$ & $\begin{array}{l}\text { To explore and further explain the phenomena of } \\
\text { supplier participation in addressing the } \\
\text { sustainability-oriented objectives of a supply chain. }\end{array}$ & $\begin{array}{c}\text { SM: Public } \\
\text { TS: Elementary, upper elementary } \\
\text { P: Unit President, purchasing, quality end } \\
\text { operation managers }(n=4) \\
\text { SD: Environmental, economic, social }\end{array}$ & Sustainable management of supply chains. \\
\hline $\begin{array}{l}\text { Elkin } \\
(2019)[73] \\
\text { USA }\end{array}$ & $\begin{array}{l}\text { To explore the three domains of sustainability of the } \\
\text { Farm-to-School program (classroom, cafeteria, and } \\
\text { community) developed in a California School District. }\end{array}$ & $\begin{array}{c}\text { SM: Public } \\
\text { TS: Elementary, middle } \\
\text { P: School district }(n=1) \\
\text { SD: Environmental, economic, social }\end{array}$ & $\begin{array}{l}\text { Participation in the "Farm-to-School" } \\
\text { program (local food, school garden; teaching } \\
\text { about food, farming, and agriculture). }\end{array}$ \\
\hline $\begin{array}{l}\text { Lopes, Basso, Brum } \\
\text { (2019) [74] } \\
\text { Brazil }\end{array}$ & $\begin{array}{c}\text { To evaluate the functioning of the market generated } \\
\text { by the National School Feeding Program in the school } \\
\text { network of Ijuí, RS, Brazil, from the standpoint of } \\
\text { short agrifood chains. }\end{array}$ & $\begin{array}{c}\text { SM: Public } \\
\text { TS: Elementary } \\
\text { P: Education Secretary, nutritionist, school } \\
\text { director }(n=3) \\
\text { SD: Environmental }\end{array}$ & School Garden; environmental education. \\
\hline $\begin{array}{l}\text { Santos et al. } \\
(2019)[75] \\
\text { Brazil }\end{array}$ & $\begin{array}{l}\text { To implement a school vegetable garden using } \\
\text { recyclable materials. }\end{array}$ & $\begin{array}{c}\text { SM: Public } \\
\text { TS:Elementary } \\
\text { P: School }(n=1) \\
\text { SD: Environmental, economic }\end{array}$ & $\begin{array}{l}\text { Organic school garden with recycled material } \\
\text { (tires). }\end{array}$ \\
\hline $\begin{array}{l}\text { Blondin et al. } \\
\text { (2020) [25] } \\
\text { USA }\end{array}$ & $\begin{array}{c}\text { To assess the Meatless Monday campaign's } \\
\text { nutritional, environmental, and environmental } \\
\text { impacts in the National School Lunch Program in a } \\
\text { US school district. }\end{array}$ & $\begin{array}{c}\text { SM: Public } \\
\text { TS: Not informed } \\
\text { P: School district }(n=1) \\
\text { SD: Environmental, economic }\end{array}$ & Reduced meat supply. \\
\hline $\begin{array}{l}\text { Derqui, Grimaldi, Fernandez } \\
\text { (2020) [26] } \\
\text { Spain }\end{array}$ & $\begin{array}{l}\text { To understand the level of awareness about food } \\
\text { waste generated, of interventions applied to minimize } \\
\text { it, and to categorize the schools and prioritize a list of } \\
\text { interventions to reduce food waste in school canteens. }\end{array}$ & $\begin{array}{c}\text { SM: Public, private } \\
\text { TS: Elementary, high school } \\
\text { P: School headteachers }(n=420) \\
\text { SD: Environmental, economic, social }\end{array}$ & $\begin{array}{l}\text { Certification and training (sustainability); } \\
\text { flexible servings; composting; food donation; } \\
\text { noise reduction,; communication (adjustment } \\
\text { of the quantity produced); reduced use of } \\
\text { paper/water/energy. }\end{array}$ \\
\hline
\end{tabular}


Table 1. Cont.

\begin{tabular}{|c|c|c|c|}
\hline $\begin{array}{l}\text { Author } \\
\text { (Year) } \\
\text { Country }\end{array}$ & Objectives & $\begin{array}{c}\text { School Management (SM) } \\
\text { Teaching Stage (TS) } \\
\text { Participants (P) } \\
\text { Sustainability Dimension (SD) }\end{array}$ & Main Sustainability Practices Identified \\
\hline $\begin{array}{l}\text { Izumi et al. } \\
(2020) \text { [35] } \\
\text { Japan }\end{array}$ & $\begin{array}{l}\text { To explore factors that minimize lunch waste in } \\
\text { Tokyo elementary schools and consider how such } \\
\text { factors can be modified and applied in US schools. }\end{array}$ & $\begin{array}{c}\text { SM: Public } \\
\text { TS: Elementary } \\
\text { P: School dietitians }(n=5) \\
\text { SD: Environmental, economic }\end{array}$ & $\begin{array}{l}\text { Social norms (avoid waste); exposure to } \\
\text { unknown/unappreciated foods; pedagogical } \\
\text { practices; portion adequacy; } \\
\text { recycling; composting. }\end{array}$ \\
\hline $\begin{array}{l}\text { Prescott et al. } \\
\text { (2020) [76] } \\
\text { USA }\end{array}$ & $\begin{array}{c}\text { To identify potential school meal recovery options, } \\
\text { their prevalence, and systems factors influencing } \\
\text { school food waste recovery across three Northern } \\
\text { Colorado } \\
\text { school districts. }\end{array}$ & $\begin{array}{c}\text { SM: Public } \\
\text { TS: Not informed } \\
\text { P: Individuals engaged in food recovery }(n=28) \\
\text { SD: Environmental, social }\end{array}$ & Composting; sharing table; food donation. \\
\hline $\begin{array}{l}\text { Virta, Love } \\
(2020)[77] \\
\text { USA }\end{array}$ & $\begin{array}{l}\text { To identify how fishes are implemented in school } \\
\text { programs, their impacts, and the enabling factors to } \\
\text { support these programs. }\end{array}$ & $\begin{array}{c}\text { SM: Public } \\
\text { TS: Elementary, middle, high school } \\
\text { P: Seafood processors, Oregon Seafood } \\
\text { Commission leaders, school district food service } \\
\text { leaders, school kitchen managers }(n=6) \\
\text { SD: Environmental, economic, social }\end{array}$ & $\begin{array}{l}\text { Participation in the "Fish to School" program } \\
\text { (offer and education about local seafood). }\end{array}$ \\
\hline $\begin{array}{l}\text { Perez-Neira et al. } \\
\text { (2021) [30] } \\
\text { Spain }\end{array}$ & $\begin{array}{l}\text { To assess the greenhouse gas emissions reduction of } \\
\text { agroecological policies implemented in public food } \\
\text { procurement, specifically for school canteens. }\end{array}$ & $\begin{array}{c}\text { SM: Public } \\
\text { TS: Pre-School, lementary } \\
\text { P: School canteens }(n=\text { not informed }) \\
\text { SD: Environmental, economic, social }\end{array}$ & $\begin{array}{l}\text { Purchase of local, organic, and seasonal food } \\
\text { (agro-ecology policies). }\end{array}$ \\
\hline $\begin{array}{l}\text { Rector et al. } \\
(2021)[78] \\
\text { Tanzania }\end{array}$ & $\begin{array}{l}\text { To assess the state of adolescent school nutrition } \\
\text { interventions in Dodoma, Tanzania. }\end{array}$ & $\begin{array}{c}\text { SM: Public } \\
\text { TS: High School } \\
\text { P: School administrators, teachers, students, } \\
\text { parents ( } n=\text { not informed }) \\
\text { SD: Environmental }\end{array}$ & School garden. \\
\hline $\begin{array}{l}\text { Toledo } \\
(2021)[79] \\
\text { Brazil }\end{array}$ & $\begin{array}{l}\text { To evaluate the "Educational Garden" Program to } \\
\text { promote adequate and healthy food in the school } \\
\text { environment. }\end{array}$ & $\begin{array}{c}\text { SM: Public } \\
\text { TS: Elementary, high school } \\
\text { SD: Environmental }\end{array}$ & School Garden; environmental education. \\
\hline
\end{tabular}


In the United States, where the largest number of studies was identified $(n=22)$, sustainability practices mainly involved educational activities for sustainability [20,44,53,56,57,59-61,69], waste reduction $[40-42,46,49,61,76]$, school gardens $[20,46,55,59-61,64]$, and participation in programs that promote closer ties between schools and producers $[46,48,69,70,73,77]$. Practices such as food donation $[49,64,69,76]$, strategies for the rational use of water and energy $[42,61]$, the offer of vegetarian/vegan menus or with reduced meat supply $[25,46]$, and the use of local and organic foods (not mentioning participation in specific programs for this purpose) [59] were less mentioned. The study was carried out in parallel in the United States and Cuba in the context related to the experiences of urban school gardens in Philadelphia (USA) and Havana (Cuba) [51].

In Canada, the identified sustainability practices $(n=2)$ involved school gardens, purchase of local and organic foods, participation in programs that promote closer ties between schools and local farmers, waste reduction, and the use of vegetarian dishes [24,71]. In Brazil, the only country in Latin America in which studies were identified $(n=7)$, the most cited practices were related to school gardens $[14,45,74,75,79]$ and educational activities for sustainability, including training for those involved in the operationalization of the National School Feeding Program (PNAE) [14,68,74,79]. However, the studies also cited activities to reduce waste $[14,45,75]$, use of local [14] and regional [62] foods, partnerships for the development of sustainability activities (such as environmental preservation), and to encourage both the use of organic food and to value the work of those involved in all food production [68].

Among European countries, three studies were conducted in Spain and Italy, two in England, and one in Denmark, Finland, and Wales. The most common practices involved were buying local and organic food [8,30,47,58,67]. In Italy, socio-environmental criteria in hiring school food services were also mentioned [47]. Among the European studies, practices linked to changes in menus or portions were also identified $[8,26,27,52]$, sustainability certification [26], waste reduction and energy and/or water savings [26,50], participation in a program to encourage sustainable eating [12,54], school garden [50], and practices aimed at social sustainability (such as food donation and the use of food from land confiscated from criminal organizations) $[8,26,27]$.

On the African continent, two studies were identified in South Africa $[43,66]$ and one in Ghana [63], Tanzania [78], and Kenya [65]. The identified practices focused on activities related to school gardens $[43,66,78]$. However, the teaching of agroforestry practices, water-saving, and the development and adoption of a meal planning package nutritionally balanced meals, with locally sourced ingredients, were also identified in the studies $[43,63,65]$.

Among Asian countries, one study was identified in Japan [35] and one in India [72]. In Japan [35], the study demonstrated that the reinforcement of social norms not to waste and factors related to the planning of menus, pedagogical practices, and recycling and composting activities, contributed to reducing the food waste in schools. In India, the sustainable management of supply chains was studied based on one of the companies responsible for the school feeding program, which considers the integration of economic and non-economic issues in the generation of value in the supply chain [72].

In $20 \%$ of the studies $(n=10)$, it was impossible to identify information about the responsibility for managing schools. Most studies were performed in public schools (64\%; $n=32)$. Studies conducted in public and private schools corresponded to $14 \%(n=7)$, and only one study was conducted in a private school. All stages of the education system, including the earliest (pre-school) and the final years (high school), were mentioned, but the stage referring to primary or elementary education was identified in most studies (68\%; $n=34)$. In $27.4 \%$ of the studies $(n=14)$, it was impossible to obtain this information. The studies used quantitative $(30 \% ; n=15)$, qualitative $(48 \%$; $n=24)$, or mixed methods $(22 \%$; $n=11)$. 


\subsection{Identified Sustainability Practices}

The environmental dimension of sustainability was identified in all studies that cited sustainability practices $(n=50)$, alone $(26 \% ; n=13)$, or together with the other considered dimensions. In most studies $(44 \% ; n=22)$, it was possible to identify practices related to the three sustainability dimensions (environmental, economic, and social). The combination of environmental and social dimensions was identified in $14 \%$ of the studies $(n=7)$, and the environment with economic dimension in $16 \%(n=8)$. It is important to highlight that for identifying the sustainability dimensions, some practices, in isolation, represented the attendance of more than one of the mentioned dimensions. In contrast, in other cases, the identification of different sustainability dimensions in the same study resulted from different practices cited by the authors. Sustainability practices adopted in schools are presented in Table 1. The activities were described according to the dimensions of sustainability (Figure 2).

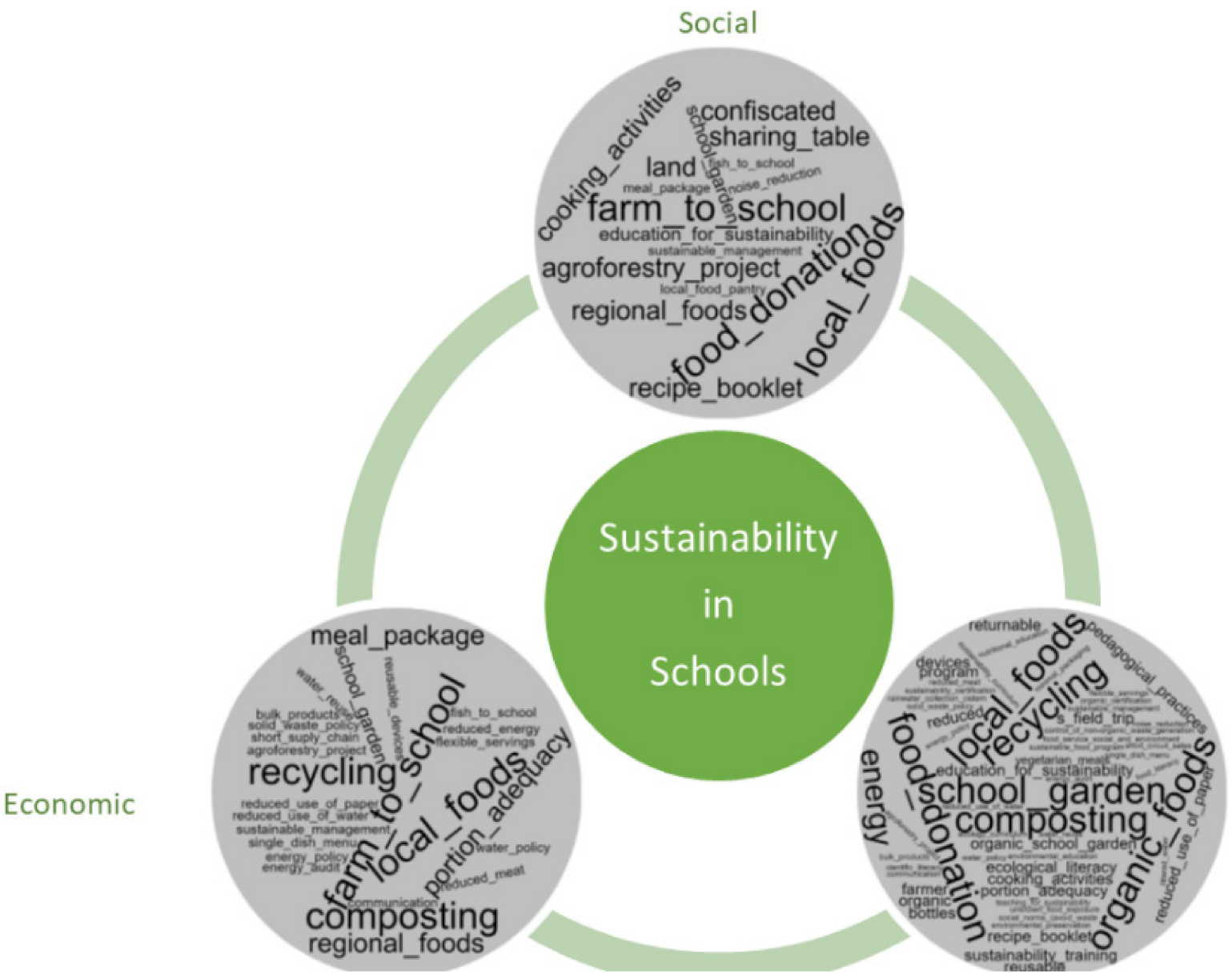

Environment

Figure 2. Identified sustainable practices in schools according to the environmental, economic, and social dimensions.

The involvement with school gardens and education activities for sustainability represented the most commonly reported practices, being identified in $36 \%(n=18)[14,20,24,43$, $45,46,50,51,55,59-61,64,66,74,75,78,79]$ and $28 \%(n=14)[14,20,35,44,51,53,56,57,59-61,69,74,79]$ of the studies, respectively. Among the studies that described the use of school gardens, $8 \%(n=4)[14,45,61,75]$ described the cultivation of organic foods and, in the context of education practices for sustainability, travel field studies $[59,60]$ and cooking activities $[14,20,44,69]$ were also cited.

Another frequently cited category of sustainability practices concerns schools food supply initiatives. Actions to purchase or encourage the employment of local or short-chain 
foods, including participation in programs such as "Farm to School" and "Fish to School" were cited by $26 \%(n=13)$ of the studies $[8,14,24,30,46,48,59,67,69-71,73,77]$ and organic foods were observed in $18 \%(n=9)[8,24,30,45,47,58,59,67,68]$. Participation in a sustainable food consumption promotion program $(4 \% ; n=2)$ was also identified [12,54]. Although little mentioned, practices that integrated socio-environmental and economic dimensions in the contracts $(4 \% ; n=2)$, the use of regional $(2 \% ; n=1)$, seasonal $(2 \% ; n=1)$, and produced foods in lands confiscated from criminal organizations, were also observed [8,30,47,62,72].

Regarding the adoption of measures to reduce waste, recycling [35,40-42,46,49,50] and composting $[24,26,35,46,49,61,76]$ were the most reported, described in $14 \%(n=7)$ of the analyzed studies. These represent important strategies for the control of organic and inorganic waste. Food donation was a practice identified in $10 \%(n=5)$ of the studies $[26,27,49,64,76]$ and food portion size adjustment in $6 \%(n=3)[26,27,35]$. Sharing tables [76], single-course menu [8], reinforcement of social norms [35], donation of food waste for animal feeding [49], team communication to adjust the amount produced, and noise reduction in the cafeteria to allow a more comfortable environment [26] were also identified practices for the reduction of organic waste, to a lesser degree than the others previously mentioned. Other less cited practices involving the control of non-organic waste generation were the use of reusable devices [40,45], the purchase of products in bulk or with minimum packaging [24,40], the use of returnable bottles [14], reduced use of paper [26], or the replacement of mineral water by filtered water [8].

The adoption of strategies that involved saving water or energy was cited in $10 \%$ $(n=5)$ of the studies $[26,42,43,50,61]$, represented by activities such as reduced use of energy, energy audits, reduced use of water, and installing a cistern for collection rainwater or irrigation system for water reuse.

As for menu actions, practical studies were identified as offering vegetarian/vegan meals [24,46,52], reducing meat supply [25], planning a menu that included the exposure of students to unfamiliar or unappreciated foods [35], and the adoption of a meal planning package that facilitated the planning of nutritionally balanced meals with locally sourced ingredients [63].

Although mentioned in only one study, partnerships for the development of sustainability activities (such as environmental preservation) and certification were also identified $[26,68]$.

\subsection{Sustainability Recommendations in School Feeding Policies/Programs}

Among the 11 policies under government responsibility identified in the studies that mentioned sustainability recommendations, $73 \%(n=8)$ were national in scope, $18 \%$ $(n=2)$ state, and 9\% $(n=1)$ municipal. The European continent had the highest number of policies/programs $(64 \% ; n=7)$, identified in Italy, England, Finland, Spain, Sweden, and Germany [37,80-85]. School feeding policies/programs were also identified in Brazil, Japan, and the United States [34,86-89] (Table 2).

The most mentioned aspects were the origin and type of food used in school meals, such as organic, local or shorter transport distances, seasonal, agroecological, and sustainable $[34,37,80-87]$. Other examples cited in this category, although less frequently, were reducing meat, increasing consumption of vegetables, reducing carbon emissions, typical foods, and respecting local traditions $[34,37,82,84,86]$. 
Table 2. Identified Sustainability recommendations in governmental school food policies documents.

\begin{tabular}{|c|c|c|c|c|c|}
\hline Year (Reference) & Document & Document Type & Responsibility & City/Country & Identified Sustainability Recommendations \\
\hline $\begin{array}{l}\text { Municipality of Barcelona } \\
\text { (2020) [82] }\end{array}$ & $\begin{array}{l}\text { This Is Not a Drill. Climate } \\
\text { Emergency Declaration, Barcelona. }\end{array}$ & Declaration & Municipal & Barcelona (Spain) & $\begin{array}{l}\text { Implementation and promotion of healthier and } \\
\text { low-carbon diets in schools through the use of } \\
\text { seasonal, local and organic foods; reduction of } \\
\text { animal protein intake (especially red meat) and } \\
\text { ultra-processed foods. }\end{array}$ \\
\hline $\begin{array}{l}\text { The National Food Agency } \\
\qquad(2021) \\
{[84]}\end{array}$ & $\begin{array}{l}\text { Good school meals. Guidelines for } \\
\text { primary schools, secondary schools, } \\
\text { and youth recreation centers. }\end{array}$ & Guideline & National & Sweden & $\begin{array}{l}\text { Topics on menu planning (including, among } \\
\text { others, reducing meat and increasing vegetables, } \\
\text { legumes, fruits, and cereals, choosing organic } \\
\text { foods, and observing seasonality), measures to } \\
\text { prevent food waste, reducing energy } \\
\text { consumption, and transport distance. }\end{array}$ \\
\hline $\begin{array}{c}\text { Brazil (2009)/Brazil (2020) } \\
{[34,86]}\end{array}$ & $\begin{array}{c}\text { Law } n^{\circ} \text { 11.947, from } 16 \text { June } \\
\text { 2009/Resolution FNDE } n^{\circ} \text { 06, May } \\
2020 \text {. }\end{array}$ & Law/Resolution & National & Brazil & $\begin{array}{l}\text { Support for sustainable development through } \\
\text { purchasing local food from family farming, } \\
\text { preference for organic and agroecological food, } \\
\text { observation of sustainability in menu planning, } \\
\text { and nutrition education actions, seasonality; } \\
\text { local traditions. }\end{array}$ \\
\hline $\begin{array}{l}\text { Cabinet Office Japan (1954) } \\
\text { [88] }\end{array}$ & School Lunch Program Act. & Law & National & Japan & $\begin{array}{l}\text { Respect for nature; a positive attitude towards } \\
\text { environmental conservation; a sense of valuing } \\
\text { the work of those involved in food production; } \\
\text { food education; generation of a correct } \\
\text { understanding of the production, distribution, } \\
\text { and consumption of food. }\end{array}$ \\
\hline
\end{tabular}


Table 2. Cont.

\begin{tabular}{|c|c|c|c|c|c|}
\hline Year (Reference) & Document & Document Type & Responsibility & City/Country & Identified Sustainability Recommendations \\
\hline $\begin{array}{l}\text { United States Department } \\
\text { of Agriculture (2015) } \\
\text { [89] }\end{array}$ & $\begin{array}{c}\text { Updated Offer versus Serve } \\
\text { Guidance for the National School } \\
\text { Lunch Program and School Breakfast } \\
\text { Program Effective Beginning School } \\
\text { Year 2015-2016. }\end{array}$ & Guidance & National & USA & $\begin{array}{l}\text { The possibility of the student refusing some of } \\
\text { the foods offered to reduce food waste in school } \\
\text { feeding programs. }\end{array}$ \\
\hline Santa Catarina (2018) [87] & Law 17.504, 10 April 2018. & Law / Resolution & State & Brazil & $\begin{array}{l}\text { Preference for the purchase of organic } \\
\text { vegetables by schools, foreseeing a gradual } \\
\text { increase in the percentage of purchases. }\end{array}$ \\
\hline $\begin{array}{l}\text { National Nutrition Council } \\
\qquad \begin{array}{c}(2017) \\
{[81]}\end{array}\end{array}$ & $\begin{array}{l}\text { Eating and learning } \\
\text { together-recommendations for } \\
\text { school meals. }\end{array}$ & Recommendations & National & Finland & $\begin{array}{l}\text { Sustainable development and environmental } \\
\text { issues concerning food acquisition, food choices, } \\
\text { and waste reduction, citing, among others, } \\
\text { seasonality; favoring the consumption of } \\
\text { domestic vegetables; assembly of dishes by } \\
\text { students; possibility of repetition. }\end{array}$ \\
\hline $\begin{array}{l}\text { Department for Education } \\
\qquad(2021) \\
{[80]}\end{array}$ & $\begin{array}{l}\text { School food standards practical } \\
\text { guide. }\end{array}$ & Guidance & National & England & $\begin{array}{l}\text { It recommended sustainable procurement, } \\
\text { including the use of fresh, seasonal, sustainable, } \\
\text { and locally sourced ingredients, sustainable fish } \\
\text { purchase, waste reduction, and school gardens. }\end{array}$ \\
\hline $\begin{array}{l}\text { Consejo Interterritorial de } \\
\text { Sistema Nacional de Salud } \\
\qquad(2010) \\
{[83]}\end{array}$ & $\begin{array}{l}\text { Consensus document about food in } \\
\text { educational centers. }\end{array}$ & Consensus & National & Spain & $\begin{array}{l}\text { It informed that the possible incorporation of } \\
\text { organic food in school lunches might have } \\
\text { advantages about sustainability and protection } \\
\text { of the environment. However, it considered no } \\
\text { evidence to affirm that organic foods are } \\
\text { nutritionally better or safer. }\end{array}$ \\
\hline $\begin{array}{l}\text { Senate Administration } \\
\text { (2017) [85] }\end{array}$ & $\begin{array}{c}\text { Reorganization of the school lunch at } \\
\text { open and affiliated all-day primary } \\
\text { schools and for support centers in } \\
\text { Berlin. }\end{array}$ & Handout & State & Berlin (Germany) & $\begin{array}{l}\text { The establishment of criteria for quality } \\
\text { assessment, considered a priority about the } \\
\text { price when hiring school food suppliers (organic } \\
\text { food corresponds to one of the quality criteria). }\end{array}$ \\
\hline
\end{tabular}


Regarding other non-governmental programs and initiatives $(n=5)$, two were identified in the United States [90,91], two were global in scope [92,93], and one was identified in England [94]. The set of activities observed in these programs involved encouraging the purchase of local, seasonal, and sustainable food [91,92,94], school gardens [91,94], visits to local farmers [91,94], cooking and nutritional education activities [91,94], waste reduction [90], and specific actions for each school to train people to generate environmental and sustainability awareness [93] (Table 3).

\subsection{Risk of Bias}

Among the studies analyzed, 49 had a low risk of bias and 1 had a moderate risk. All studies implemented the practices and answered the main research question (Table S2-Supplementary Materials). 
Table 3. Other available non-governmental school feeding programs/initiatives retrieved from the studies.

\section{Initiative} Country

Food for Life Partnership (FFLP) [94]

England

Eco-Schools [93]

Global

Home Grown School Feeding [92]

Smarter Lunchrooms Movement (SLM) [90]

Global

USA

Farm to School (FTS) [91]

\section{Description}

A program with a whole-school approach that addresses healthy, tasty, and sustainable eating through four areas of development: food quality, food leadership and food culture, food education, and community and partnerships. "Food quality" includes, among other factors, the use of fresh, seasonal, local, and organic foods, meat that meets animal welfare standards, marine conservation certified fish, and eggs from free range hens. "Nutritional education" includes the development of cooking skills, planting food and visiting or receiving visits from farmers, in addition to ethical and environmental issues around food choices.

A global program of sustainable schools that aims to train people with an environmental and sustainability conscience. The program is based on seven steps, the: formation of an Eco Committee (in which students play a main role) to discuss environmental and social actions for the school, conduction of a sustainability audit, preparation, monitoring, and evaluation of the action plan, linking of activities to the curriculum, information and involvement with the community, and production of an ecological code that represents the school's commitment to sustainability.

An initiative in which the World Food Program works with governments to develop school food policies that seek to improve student nutrition and support the local economy through the connection between school food and local farmers.

The initiative generated by research in schools is used to create lunchrooms that encourage healthy food choices and reduce waste, using a strategy with little or no cost.

It connects schools and local food producers to offer fresh and healthy food to students. It is based on local food purchasing activities, education about food, nutrition, health, agriculture, and hands-on learning activities (school gardens, including visits to local farmers and culinary classes). 


\section{Discussion}

In 2019, the EAT-The Lancet Commission established universal strategies and recommendations to achieve food system transformation, striving for human health and environmental sustainability. The need to improve availability and access to healthy foods from sustainable food systems and educate individuals on these topics using food programs was reinforced [95]. Therefore, the school is an opportune locus for sustainability practices. The environmental, economic, and social effects of the actions carried out in school food services and the education process will echo both in society's present and future.

Vegetable gardens and education activities for sustainability were the most cited practices among the studies. School gardens are essential tools to support community and school feeding programs by using their produce in student meals and training vegetable growing skills $[19,43,66]$. However, the support of the school administration, the availability of space and resources to purchase tools and supplies, teacher training, the integration of the garden into the school curriculum, sharing activities with community members, and the presence of a coordinator to organize activities are identified as key factors in determining the results of the implementation and continuity of school gardens [66,96,97].

Education plays a central role in enabling students to think and act critically on current and future global challenges, including climate change, environmental degradation, biodiversity loss, poverty, and inequality [16]. Therefore, the literature has strongly recommended and evidenced the association between school gardens and educational processes aimed at health, environment, and sustainability [19,24,61]. Gonsalves et al. [19] emphasize the role of school gardens "in environmental and nature education, in local food biodiversity and conservation, food, eco-literacy, diets, nutrition and health, and agricultural education, contributing to the search for a food system more sustainable."

The importance of education in enabling individuals to promote sustainable development is reaffirmed in Sustainable Development Goal 4 (SDG 4). SDG 4 is integrated with other indivisible goals, comprising the environmental, economic, and social dimensions of Agenda 2030, an action plan for people, the planet, and prosperity [98].

In line with this purpose, schools can observe efforts to integrate environmental education, ecological literacy, or education for sustainability in their curricula $[14,56,57,60,69]$. However, a recent study [99] that assessed the extent to which environmental issues are integrated into primary and secondary education policies and curricula in 46 member states of the United Nations Educational, Scientific, and Cultural Organization (UNESCO) demonstrated that despite $92 \%$ of the documents making some reference to environmental issues, the depth of this inclusion was low. Terms such as "climate change" and "biodiversity" were rarely mentioned. What has been done is not enough to ensure that learning helps in confronting current global challenges. The document recommends, among other actions, that greater emphasis needs to be placed on environmental issues in education, integrating them into curricula and overcoming the focus on cognitive knowledge, and training all teachers and school leaders in education for sustainable development [99]. Also, considering the food system's environmental, economic, and social impacts, the efforts to integrate themes involving sustainable food consumption into educational practices are worthy of note $[12,44]$. These approaches are fundamental because education can increase adherence to different sustainability practices since, although observed in this study, many had a low frequency of realization.

The use of local or organic foods, often set by government regulations, stems from concerns about students' health, the living conditions of farmers, and the environment $[34,47,48,70,100]$. Initiatives involving the use of local and organic foods were also frequently cited among the analyzed studies $[8,14,24,30,47,58,59,67]$.

The creative food purchase policy incorporates social and environmental criteria into the contracts, going beyond economic considerations and encouraging the purchase of local food [33]. Examples of buying local and organic food are worldwide, as in the 
Brazilian case at the National School Feeding Program, where the purchase of food from local farmers is a compulsory item provided in its legal framework. Organic food is preferred in public purchases, the standardized instruments for this type of purchase in the country's program [34]. Through Home Grown School Feeding, the World Food Program (WFP) works with governments in 46 countries to develop national policies that provide adequate food for students and ensure local development by purchasing food from family farmers [92]. There are also experiences linked to the Farm To School programs, which purchase local food and develop educational activities related to agriculture, food, health, and nutrition $[70,71]$. All initiatives that connect schools to family farmers are vital because the benefits of school meals go beyond the boundaries of schools and reach family farmers. These involve economic (increase in income, price support, and inclusion in the market), social (food security, living conditions, and social inclusion), and environmental (crop diversification and greater production of organic food) aspects [31].

Reducing food waste and controlling non-organic waste represent initiatives that must be implemented in school food services. Studies in different parts of the world have demonstrated that these places are major food waste generators, causing environmental, economic, and social impacts [101-104]. Concerning non-organic waste, a study carried out in northern Colorado, USA identified that factors such as the speed of the service line, the quality of food, the cost, and the difficulty managers have in understanding the impact of their decisions at a systemic level, affected the ability to reduce or recover these wastes [105].

In our systematic review, composting was the most cited practice for reducing the generation of organic waste and recycling non-organic waste. However, it is important to highlight that even among the studies in which the performance of waste management practices was cited, they were often not reported among the participants or were reported by a minority of them $[26,40-42,46,49,76]$, demonstrating that adopting waste reduction strategies in school meals is not yet routine practice.

Among the strategies to promote the reduction of food waste, the literature discusses the importance of integrating this theme and the sustainability of the food system in pedagogical practices, in addition to actions aimed at improving operations and planning, team communication, and the involvement of students in waste management activities [35,102]. Food donation can represent a successful experience to mitigate the impacts of the production of meals by reducing waste and serving people in vulnerable situations, with relatively few investments [27]. However, the main barriers related to food donation and food recovery in this context involve concerns about responsibility, cost, inconsistent food waste, policy confusion, and the sanitary quality of food [76]. As for non-organic waste, among other recommendations, a study indicated that school food services could incorporate packaging waste in purchasing processes, as they do not always control the packaging used by manufacturers [105].

The adoption of some strategies related to saving water and energy was mentioned among the analyzed studies. In school feeding, studies that reported the environmental impacts of the choices made by food services regarding the origin and types of food purchased (fresh or not, and from different groups, such as meat and vegetables) demonstrated a significant contribution from phases before the production of meals $[21,23,106]$. However, considering that during the production of meals both water and energy are essential factors for the operation of the service, the training of a school's employees and the monitoring of the intended use of these resources is necessary. Instruments created to evaluate sustainability practices in food services, which include among their analysis categories the rational use of energy and water, are helpful tools in this regard $[107,108]$.

Environmental and health damage to the population generated by how the food system has been operated is already well established [109]. Two of the factors contributing to the harmful effects of this modus operandi are meat production, especially red meat, and food waste, which are responsible, among other factors, for a significant emission of greenhouse gases into the environment and/or consumption of freshwater $[23,106,110,111]$. 
Therefore, some practices related to the offer of vegetarian/vegan menus, with a reduction in the meat offering, the adequacy of the portion sizes, or the adoption of the single-course scholar menu have been reported in the literature [8,25-27,35,112]. Some instruments have been proposed to allow the planning of more environmentally sustainable menus based on reducing carbon and/or water footprints while addressing nutritional, economic, and cultural dimensions [7,113-116]. In addition, the definition of criteria for planning sustainable menus in the context of school meals has also been described [117].

Other less mentioned strategies involved using regional foods, environmental certification, and the development of partnerships to carry out environmental preservation activities.

According to Morgan [118], "the creation of a sustainable school foodservice is the litmus test of a country's commitment to sustainable development, as it involves nothing less than the health and well-being of young people and vulnerable people". In this sense, several efforts were made to strengthen the role of school feeding in achieving nutritionally adequate diets for students and meet the principles of sustainability in the three dimensions: environmental, economic, and social. However, it is noteworthy that, despite the general premise established in the literature of the potential effects of sustainability practices in school in mitigating global challenges, the wide scope of school feeding and the variability of characteristics and challenges experienced between different regions of the globe, including different regulations, economic, social, political and cultural conditions, demand specific solutions, adapted to each local context.

\section{Limitations}

This review has some limitations. First, it was not possible to state that the school feeding policies/programs that mentioned concerns about sustainability were exhausted, since the policies were found in the studies reference lists that had their full text analyzed. In addition, some of these policies, written in a non-English language, were translated through a translation platform. Therefore, some information may have been lost due to language barriers. Despite these limitations, these findings evidenced different recommendations that reinforced the importance of actions, which ranged from the choice of sustainable foods to the strengths of nutrition and sustainable consumption practices education.

\section{Conclusions}

There is an imminent need to ensure the prosperity of nations, anchored in the priorities of protecting the health of people and the planet and guaranteeing adequate living conditions, reducing social inequalities. It involves offering food in terms of education, enabling students to make conscious choices consistent with this need. In this sense, schools and school feeding programs have all the necessary characteristics for developing practices that aim at sustainability in the environmental, economic, and social dimensions, given their scope and the different perspectives that can be worked.

The present study identified sustainability recommendations in 16 governmental and non-governmental policies/programs. Recommendations for purchasing sustainable food (organic, local, and seasonal), nutrition education focused on sustainability, and reducing food waste were frequent.

Several sustainability practices were described in this systematic review, such as the use of school gardens and education activities for sustainability. Actions carried out in food services were also mentioned, from the planning of menus and the purchase of raw materials (mainly local and organic foods, vegetarian/vegan menus) to the distribution of meals (especially practices to reduce waste organics and inorganics such as composting, recycling, donating food, and adjusting portion sizes).

The findings reinforce the need to stimulate managers' views, in their most varied spheres of power, for the priority that should be given to this theme, so that education for sustainability is universally part of the curricula, and so that food services can equip themselves with the knowledge and tools necessary to carry out sustainability practices in their daily activities. 
Lastly, further investigations to evaluate these practices are needed to examine the evolution of their adoption and the main barriers and potentialities related to their implementation. With a specific look at the school field, assessment instruments can help with this monitoring.

Supplementary Materials: The following are available online at https:/ /www.mdpi.com/article/10 .3390 / foods11020176/s1, Table S1: Databases and terms used to search references on sustainability practices adopted in schools; Table S2: Quality criteria of the studies selected for the systematic review.

Author Contributions: E.B.d.S., conceptualization, investigation, methodology, writing-original draft, writing - review and editing; D.d.C.M., investigation and methodology; R.P.Z., data curation, formal analysis, supervision, validation and writing-review and editing; A.R., writing-review and editing, visualization, project administration. R.B.A.B., data curation, formal analysis, supervision, validation and writing-review and editing. All authors have read and agreed to the published version of the manuscript.

Funding: This research received no external funding.

Institutional Review Board Statement: Not applicable.

Informed Consent Statement: Not applicable.

Data Availability Statement: No data availability.

Acknowledgments: The authors would like to acknowledge the "National Council for Scientific and Technological Development-CNPq".

Conflicts of Interest: The authors declare no conflict of interest.

\section{Appendix A}

Table A1. Full-text articles excluded, with reasons.

\begin{tabular}{lc}
\hline Author (Year) & Reason for Exclusion \\
\hline Alexandre et al. (2016) [119] & 2 \\
Amarante (2016) [120] & 1 \\
Andreatta et al. (2021) [121] & 4 \\
Anton-Peset, Fernandez-Zamudio and Pina (2021) [13] & 2 \\
Batlle-Bayer et al. (2021) [122] & 3 \\
Braun et al. (2018) [123] & 4 \\
Brena (2017) [124] & 3 \\
Carvalho (2009) [125] & 5 \\
Coleman et al. (2011) [126] & 1 \\
Colombo et al. (2019) [7] & 3 \\
Colombo et al. (2020) [127] & 2 \\
Constanty (2014) [128] & 4 \\
Constanty and Zonin (2016) [129] & 4 \\
Conner et al. (2010) [130] & 2 \\
Damapong, Kongnoo and Monarumit (2013) [131] & 1 \\
Dirks (2011) [132] & 3 \\
Eich (2015) [133] & 5 \\
Ellinder et al. (2020) [113] & 2 \\
Elnakib et al. (2021) [134] & 2 \\
Colombo (2021) [135] & 2 \\
Ferderbar (2013) [136] & 3 \\
Filippini et al. (2018) [137] & 2 \\
Fitzsimmons and O’Hara (2019) [138] & 5 \\
Franzoni (2015) [139] & 5 \\
Gaddis and Jeon (2020) [38] & 4 \\
Ghattas et al. (2020) [140] & 4 \\
Granillo-Maciías (2021) [141] & 1 \\
\hline & 2 \\
\hline
\end{tabular}


Table A1. Cont.

\begin{tabular}{|c|c|}
\hline Author (Year) & Reason for Exclusion \\
\hline Green (2016) [142] & 2 \\
\hline Gregolin et al. (2017) [143] & 4 \\
\hline He (2013) [144] & 1 \\
\hline Hendler, Ruiz and Oliveira (2021) [145] & 3 \\
\hline Henry-Stone (2008) [146] & 3 \\
\hline Hodgkinson (2011) [147] & 3 \\
\hline Johnston et al. (2009) [148] & 5 \\
\hline Jones (2012) [149] & 5 \\
\hline Kipfer (2018) [150] & 3 \\
\hline Koch (2000) [151] & 2 \\
\hline Lalli (2020) [152] & 5 \\
\hline Lauffer (2019) [153] & 2 \\
\hline Lawless (2013) [154] & 3 \\
\hline Lindgren (2020) [112] & 3 \\
\hline Løes; Nölting (2011) [28] & 1 \\
\hline Løes; Nölting (2009) [155] & 1 \\
\hline McCarty (2013) [156] & 2 \\
\hline Medina (2009) [157] & 5 \\
\hline Melão (2012) [158] & 4 \\
\hline Mikkola (2010) [159] & 1 \\
\hline Moss Gamblin (2013) [160] & 5 \\
\hline Mosiman (2014) [161] & 4 \\
\hline Morgan and Morley (2003) [162] & 1 \\
\hline Morgan and Sonino (2007) [33] & 1 \\
\hline Morgan (2008) [118] & 5 \\
\hline Mota, Silva and Pauletto (2021) [163] & 5 \\
\hline Muansrichai, Panyasing and Yonvanij (2015) [164] & 5 \\
\hline Nunes et al. (2018) [165] & 4 \\
\hline Nuutila, Risku-Norja and Arolaakso (2019) [166] & 3 \\
\hline Orr (2020) [167] & 3 \\
\hline Otsuki (2011) [168] & 4 \\
\hline Padilha et al. (2018) [169] & 4 \\
\hline Osowski and Fjellström (2018) [170] & 1 \\
\hline Polo et al. (2017) [171] & 1 \\
\hline Prescott et al. (2019) [172] & 2 \\
\hline Rambing et al. (2020) [173] & 5 \\
\hline Redman (2013) [174] & 2 \\
\hline Resque et al. (2019) [175] & 4 \\
\hline Ribeiro, Ceratti and Broch (2013) [176] & 4 \\
\hline Rodrigues et al. (2020) [107] & 2 \\
\hline Santos et al. (2014) [177] & 4 \\
\hline Schachtner-Appel (2019) [178] & 2 \\
\hline Scott (2011) [179] & 2 \\
\hline Silva and Sousa (2013) [180] & 4 \\
\hline Silva and Pedon (2015) [181] & 4 \\
\hline Silva, Gehlen and Schultz (2016) [182] & 4 \\
\hline Silva, Dias and Amorim (2015) [183] & 4 \\
\hline Soares (2011) [184] & 4 \\
\hline Soares et al. (2017) [185] & 4 \\
\hline Solof (2014) [186] & 2 \\
\hline Szinwelski et al. (2015) [187] & 4 \\
\hline Trott (2017) [188] & 2 \\
\hline Turpin (2009) [189] & 4 \\
\hline Vasconcelos, Vieira and Rodrigues (2014) [190] & 2 \\
\hline Valadão and Sousa (2018) [191] & 1 \\
\hline Wade (2019) [192] & 3 \\
\hline Wickramasinghe et al. (2016) [193] & 1 \\
\hline
\end{tabular}

Legend-Exclusion criteria: (1) Comments, letters, conferences, reviews, abstracts, reports, undergraduate works, discussion papers, and books, (2) studies carried out outside schools or in which the school was not responsible 
for the action, (3) studies in which practices were not performed or studies where activities were punctual, (4) studies focused on the supplier or that only reported purchases, and (5) studies that did not describe sustainability practices.

\section{References}

1. WFP. State of School Feeding Worldwide 2020; World Food Programme: Rome, Italy, 2020 ; p. 260.

2. Aurino, E.; Gelli, A.; Adamba, C.; Osei-Akoto, I.; Alderman, H. Food for thought? Experimental Evidence on the Learning Impacts of a Large-Scale School Feeding Program. J. Hum. Resour. 2020, 57. [CrossRef]

3. Jomaa, L.H.; McDonnell, E.; Probart, C. School feeding programs in developing countries: Impacts on children's health and educational outcomes. Nutr. Rev. 2011, 69, 83-98. [CrossRef] [PubMed]

4. Metwally, A.M.; El-Sonbaty, M.M.; El Etreby, L.A.; Salah El-Din, E.M.; Abdel Hamid, N.; Hussien, H.A.; Hassanin, A.M.; Monir, Z.M. Impact of National Egyptian school feeding program on growth, development, and school achievement of school children. World J. Pediatr. 2020, 16, 393-400. [CrossRef]

5. Locatelli, N.T.; Canella, D.S.; Bandoni, D.H. Positive influence of school meals on food consumption in Brazil. Nutrition 2018, 53, 140-144. [CrossRef] [PubMed]

6. Oostindjer, M.; Aschemann-Witzel, J.; Wang, Q.; Skuland, S.E.; Egelandsdal, B.; Amdam, G.V.; Schjøll, A.; Pachucki, M.C.; Rozin, P.; Stein, J.; et al. Are school meals a viable and sustainable tool to improve the healthiness and sustainability of children's diet and food consumption? A cross-national comparative perspective. Crit. Rev. Food Sci. Nutr. 2017, 57, 3942-3958. [CrossRef]

7. Colombo, P.E.; Patterson, E.; Elinder, L.S.; Lindroos, A.K.; Sonesson, U.; Darmon, N.; Parlesak, A. Optimizing School Food Supply: Integrating Environmental, Health, Economic, and Cultural Dimensions of Diet Sustainability with Linear Programming. Int. J. Environ. Res. Public Health 2019, 16, 3019. [CrossRef]

8. Galli, F.; Brunori, G.; Di Iacovo, F.; Innocenti, S. Co-Producing Sustainability: Involving Parents and Civil Society in the Governance of School Meal Services. A Case Study from Pisa, Italy. Sustainability 2014, 6, 1643-1666. [CrossRef]

9. WCED. Report of the World Commission on Environment and Development: Our Common Future; Oxford University Press: Oxford, UK, 1987; p. 400.

10. United Nations. Report of the United Nations Conference on Environment and Development. In Proceedings of the UN Conference on Environment and Development, Rio de Janeiro, Brazil, 3-14 June 1992; p. 72.

11. Von Koerber, K.; Bader, N.; Leitzmann, C. Wholesome Nutrition: An example for a sustainable diet. In Proceedings of the Nutrition Society, Berlin, Germany, 20-23 October 2015; Cambridge University Press: Cambridge, UK, 2017 ; Volume 76, p. 34.

12. Jones, M.; Dailami, N.; Weitkamp, E.; Salmon, D.; Kimberlee, R.; Morley, A.; Orme, J. Food sustainability education as a route to healthier eating: Evaluation of a multi-component school programme in English primary schools. Health Educ. Res. 2012, 27, 448-458. [CrossRef]

13. Antón-Peset, A.; Fernandez-Zamudio, M.A.; Pina, T. Promoting food waste reduction at primary schools. A case study. Sustainability 2021, 13, 600. [CrossRef]

14. Triches, R.M. Promoção do consumo alimentar sustentável no contexto da alimentação escolar. Trab. Educ. Saúde 2015, 13, 757-771. [CrossRef]

15. UNESCO. UN. Decade of ESD. Available online: https://en.unesco.org/themes/education-sustainable-development/what-isesd/un-decade-of-esd (accessed on 31 December 2021).

16. UNESCO. Education for Sustainable Development. Available online: https://en.unesco.org/themes/education-sustainabledevelopment (accessed on 25 November 2021).

17. Wamsler, C. Education for sustainability: Fostering a more conscious society and transformation towards sustainability. Int. J. Sustain. High. Educ. 2020, 21, 112-130. [CrossRef]

18. Benn, J.; Carlsson, M. Learning through school meals? Appetite 2014, 78, 23-31. [CrossRef]

19. Gonsalves, J.; Hunter, D.; Lauridsen, N. School gardens: Multiple functions and multiple outcomes. In Agrobiodiversity, School Gardens and Healthy Diets: Promoting Biodiversity, Food and Sustainable Nutrition; Routledge: London, UK, $2020 ;$ p. 345.

20. Strohl, C.A. Scientific Literacy in Food Education: Gardening and Cooking in School. Ph.D. Thesis, University of California, Davis, CA, USA, 2015.

21. Mistretta, M.; Caputo, P.; Cellura, M.; Cusenza, M.A. Energy and environmental life cycle assessment of an institutional catering service: An Italian case study. Sci. Total Environ. 2019, 657, 1150-1160. [CrossRef] [PubMed]

22. Jungbluth, N.; Keller, R.; König, A. ONE TWO WE-life cycle management in canteens together with suppliers, customers and guests. Int. J. Life Cycle Assess. 2015, 21, 646-653. [CrossRef]

23. De Laurentiis, V.; Hunt, D.V.L.; Rogers, C.D.F. Contribution of school meals to climate change and water use in England. Energy Procedia 2017, 123, 204-211. [CrossRef]

24. Black, J.L.; Velazquez, C.E.; Naseam, A.; Chapman, G.E.; Carten, S.; Edward, J.; Shulhan, S.; Stephens, T.; Rojas, A. Sustainability and public health nutrition at school: Assessing the integration of healthy and environmentally sustainable food initiatives in Vancouver schools. Public Health Nutr. 2015, 18, 2379-2391. [CrossRef] [PubMed]

25. Blondin, S.A.; Cash, S.B.; Griffin, T.S.; Goldberg, J.P.; Economos, C.D. Meatless Monday National School Meal Program Evaluation: Impact on Nutrition, Cost, and Sustainability. J. Hunger Environ. Nutr. 2020, 1-13. [CrossRef] 
26. Derqui, B.; Grimaldi, D.; Fernandez, V. Building and managing sustainable schools: The case of food waste. J. Clean. Prod. 2020, 243, 118533. [CrossRef]

27. Lagorio, A.; Pinto, R.; Golini, R. Food waste reduction in school canteens: Evidence from an Italian case. J. Clean. Prod. 2018, 199, 77-84. [CrossRef]

28. Løes, A.-K.; Nölting, B. Increasing organic consumption through school meals-lessons learned in the iPOPY project. Org. Agric. 2011, 1, 91-110. [CrossRef]

29. Maynard, D.d.C.; Vidigal, M.D.; Farage, P.; Zandonadi, R.P.; Nakano, E.Y.; Botelho, R.B.A. Environmental, Social and Economic Sustainability Indicators Applied to Food Services: A Systematic Review. Sustainability 2020, 12, 1804. [CrossRef]

30. Perez-Neira, D.; Simón, X.; Copena, D. Agroecological public policies to mitigate climate change: Public food procurement for school canteens in the municipality of Ames (Galicia, Spain). Agroecol. Sustain. Food Syst. 2021, 45, 1528-1553. [CrossRef]

31. Cervantes-Zapana, M.; Yagüe, J.L.; De Nicolás, V.L.; Ramirez, A. Benefits of public procurement from family farming in Latin-AMERICAN countries: Identification and prioritization. J. Clean. Prod. 2020, 277, 123466. [CrossRef]

32. Da Cunha, W.A.; de Freitas, A.F.; Salgado, R.J.S.F. Efeitos dos programas governamentais de aquisição de alimentos para a agricultura familiar em Espera Feliz, MG. Rev. Econ. Sociol. Rural 2017, 55, 427-444. [CrossRef]

33. Morgan, K.; Sonnino, R. Empowering consumers: The creative procurement of school meals in Italy and the UK. Int. J. Consum. Stud. 2007, 31, 19-25. [CrossRef]

34. Brasil. Lei no 11.947, de 16 de Junho de 2009. 2009. Available online: https://www.fnde.gov.br/index.php/legislacoes/ institucional-leis/item/3345-lei-n-11947-de-16-de-junho-de-2009 (accessed on 31 December 2021).

35. Izumi, B.T.; Akamatsu, R.; Shanks, C.B.; Fujisaki, K. An ethnographic study exploring factors that minimize lunch waste in Tokyo elementary schools. Public Health Nutr. 2020, 23, 1142-1151. [CrossRef]

36. WFP. How School Meals Contribute to the Sustainable Development Goals; World Food Programme: Rome, Italy, 2017 ; p. 8.

37. Ministero della Salute. Linee di Indirizzo Nazionale per la Ristorazione Ospedaliera, Assistenziale e Scolastica; Ministero della Salute: Rome, Italy, 2021; Volume 1, pp. 1-65.

38. Gaddis, J.E.; Jeon, J. Sustainability transitions in agri-food systems: Insights from South Korea's universal free, eco-friendly school lunch program. Agric. Human Values 2020, 37, 1055-1071. [CrossRef]

39. Page, M.J.; McKenzie, J.E.; Bossuyt, P.M.; Boutron, I.; Hoffmann, T.C.; Mulrow, C.D.; Shamseer, L.; Tetzlaff, J.M.; Akl, E.A.; Brennan, S.E.; et al. The PRISMA 2020 statement: An updated guideline for reporting systematic reviews. PLoS Med. 2021, 18, e1003583. [CrossRef] [PubMed]

40. Mann, N.L. A Decision Model for Solid Waste Management in School Food Service. Ph.D. Thesis, Texas Woman's University, Denton, TX, USA, 1991.

41. Ghiselli, R.F. Reusing, Reducing, and Recycling Solid Waste in Indiana School Food Service: A Cost-Effective Approach. Ph.D. Thesis, Purdue University, West Lafayette, IN, USA, 1993.

42. Hackes, B.L.; Shanklin, C.W. Factors Other than Environmental Issues Influence Resource Allocation Decisions of School Foodservice Directors. J. Am. Diet. Assoc. 1999, 99, 944-949. [CrossRef]

43. Albertse, G.; Mancusi-Materi, E. Children ensuring their own food security in South Africa. Development 2000, 43, 105-108. Available online: https:/ / doi-org.ez54.periodicos.capes.gov.br/10.1057/palgrave.development.1110126 (accessed on 31 December 2021). [CrossRef]

44. Wadsworth, K.G. A Process and Outcome Evaluation of EarthFriends: A Curriculum Designed to Teach Elementary School-Aged Children to Make Environmentally Sustainable Food Choices. Ph.D. Thesis, Columbia University, New York, NY, USA, 2002.

45. Lima, E.E. Alimentos Orgânicos na Alimentação Escolar Pública Catarinense: Um Estudo de Caso. Master's Thesis, Universidade Federal de Santa Catarina, Florianópolis, Brazil, 2006.

46. Vogt, R.A. Improving School Nutrition with Sustainable Food Systems. Ph.D. Thesis, University of California, Davis, CA, USA, 2006.

47. Sonnino, R. Quality food, public procurement, and sustainable development: The school meal revolution in Rome. Environ. Plan. A Econ. Space 2009, 41, 425-440. [CrossRef]

48. Izumi, B.T.; Alaimo, K.; Hamm, M.W. Farm-to-School Programs: Perspectives of School Food Service Professionals. J. Nutr. Educ. Behav. 2010, 42, 83-91. [CrossRef]

49. Baca, J. Investigating Waste Management Programs in School Foodservice Operations. Master's Thesis, Texas Woman's University, Denton, TX, USA, 2011.

50. Bennell, S.J. ESDGC in Primary Schools: Exploring Practice, Development and Influences. Ph.D. Thesis, Bangor University, Bangor, UK, 2012.

51. Bucher, K.A. Sowing City Schools: Teachers and Garden Education in Havana and Philadelphia. Ph.D. Thesis, Indiana University, Bloomington, IN, USA, 2012.

52. Lombardini, C.; Lankoski, L. Forced Choice Restriction in Promoting Sustainable Food Consumption: Intended and Unintended Effects of the Mandatory Vegetarian Day in Helsinki Schools. J. Consum. Policy 2013, 36, 159-178. [CrossRef]

53. O'Brien, B. Religion, Ethics, Nature in Secondary School Education: Exploring Religion's Role in Sustainability Trends. Ph.D. Thesis, University of Florida, Gainesville, FL, USA, 2013.

54. Orme, J.; Matthew, J.; Salmon, D.; Weitkamp, E.; Kimberlee, R. A process evaluation of student participation in a whole school food programme. Health Educ. 2013, 113, 168-182. [CrossRef] 
55. Rilla, C. School Garden Design as Catalyst for Environmental Education and Community Engagement: Los Angeles Unified School District Case Studies. Master's Thesis, University of Southern California, Los Angeles, CA, USA, 2013.

56. Shuttleworth, J.M. Teaching Sustainability as a Social Issue: Learning from Three Teachers. Ph.D. Thesis, Columbia University, New York, NY, USA, 2013.

57. Barnett, C.M. Paradigm Shift in Public Education: Ridge and Valley Charter School 2000-2014. Ph.D. Thesis, Drew University, Madison, NJ, USA, 2014.

58. He, C.; Mikkelsen, B.E. The association between organic school food policy and school food environment: Results from an observational study in Danish schools. Perspect. Public Health 2014, 134, 110-116. [CrossRef] [PubMed]

59. Keller, R.A. Fostering sustainability: A qualitative interview study exploring how educators work to cultivate nature awareness in young children. Master's Thesis, Mills College, Oakland, CA, USA, 2014.

60. Bamford, $\mathrm{K}$. The role of motivation and curriculum in shaping prosustainable attitudes and behaviors in students. Master's Thesis, The University of Vermon, Burlington, NJ, USA, 2015.

61. Coe, M.A. Influential Environments: School Gardens Impacting Arizona Children's Environmental Perspectives. Master's Thesis, The University of Arizona, Tucson, AZ, USA, 2015.

62. Fabri, R.K.; Proenca, R.P.D.C.; Martinelli, S.S.; Cavalli, S.B. Regional foods in Brazilian school meals. Br. Food J. 2015, 117, 1706-1719. [CrossRef]

63. Fernandes, M.; Galloway, R.; Gelli, A.; Mumuni, D.; Hamdani, S.; Kiamba, J.; Quarshie, K.; Bhatia, R.; Aurino, E.; Peel, F.; et al. Enhancing Linkages Between Healthy Diets, Local Agriculture, and Sustainable Food Systems: The School Meals Planner Package in Ghana. Food Nutr. Bull. 2016, 37, 571-584. [CrossRef] [PubMed]

64. Bareng-Antolin, N. High School Gardens Program across the Nation: Current Practices, Perceived Benefits, Barriers, and Resources. Master's Thesis, University of Nevada, Las Vegas, NV, USA, 2017.

65. Borish, D.; King, N.; Dewey, C. Enhanced community capital from primary school feeding and agroforestry program in Kenya. Int. J. Educ. Dev. 2017, 52, 10-18. [CrossRef]

66. Laurie, S.M.; Faber, M.; Maduna, M.M. Assessment of food gardens as nutrition tool in primary schools in South Africa. South Afr. J. Clin. Nutr. 2017, 30, 20-26. [CrossRef]

67. Soares, P.; Martínez-Mián, M.A.; Caballero, P.; Vives-Cases, C.; Davó-Blanes, M.C. Local food production for school feeding programmes in Spain. Gac. Sanit. 2017, 31, 466-471. [CrossRef]

68. Garcia, J.R.N. O Programa Nacional de Alimentação Escolar como Promotor do Desenvolvimento Rural Sustentável e da Segurança Alimentar e Nutricional em Marechal Cândido Rondon-PR. Master's Thesis, Universidade Estadual do Oeste do Paraná, Marechal Cândido Rondon, Brazil, 2018.

69. Huston, W.G. Implementing Education for Sustainability in Rural Elementary Schools: A Collective Case Study of How Leadership Impacts the Implementation of Education for Sustainability in Rural Elementary Schools in Northern New England. Ph.D. Thesis, New England College, Henniker, NH, USA, 2018.

70. Lehnerd, M.E. Investigating the Adoption and Impact of Nutrition Incentive and Farm to School Programs. Ph.D. Thesis, Tufts University, Medford, MA, USA, 2018.

71. Powell, L.J.; Wittman, H. Farm to school in British Columbia: Mobilizing food literacy for food sovereignty. Agric. Human Values 2018, 35, 193-206. [CrossRef]

72. Roy, V.; Charan, P.; Schoenherr, T.; Sahay, B.S. Ensuring supplier participation toward addressing sustainability-oriented objectives of the mid-day meal supply chain: Insights from The Akshaya Patra Foundation. Int. J. Logist. Manag. 2018, 29 , 456-475. [CrossRef]

73. Elkin, S. Comprehensive Farm-to-School: A Mixed-Methods Case Study of the Classroom, Cafeteria, and Community. Ph.D. Thesis, The University of Vermont, Burlington, NJ, USA, 2019.

74. Lopes, I.D.; Basso, D.; Brum, A.L. Cadeias agroalimentares curtas e o mercado de alimentação escolar na rede municipal de Ijuí, RS. Interações 2019, 20, 543-557. [CrossRef]

75. Dos Santos, A.M.; Baracuhy, M.P.; Furtado, D.A.; Leal de Morais, F.T.; da Silva Felix, A. Implementation of a project for the organic agriculture experience in rural schools: Climate studies, vegetable gardens, and free-range poultry production. J. Anim. Behav. Biometeorol. 2019, 7, 66-72.

76. Prescott, M.P.; Grove, A.; Bunning, M.; Cunningham-Sabo, L. A systems examination of school food recovery in Northern Colorado. Resour. Conserv. Recycl. 2020, 154, 104529. [CrossRef]

77. Virta, A.; Love, D.C. Assessing fish to school programs at 2 school districts in Oregon. Health Behav. Policy Rev. 2020, 7, 557-569. [CrossRef]

78. Rector, C.; Afifa, N.N.; Gupta, V.; Ismail, A.; Mosha, D.; Katalambula, L.K.; Vuai, S.; Young, T.; Hemler, E.C.; Wang, D.; et al. School-Based Nutrition Programs for Adolescents in Dodoma, Tanzania: A Situation Analysis. Food Nutr. Bull. 2021, 42, 378-388. [CrossRef]

79. Toledo, A.D. Promoção da Alimentação Saudável no Ambiente Escolar: Avaliação do Programa Horta Educativa em Escolas Estaduais de São Paulo. Ph.D. Thesis, Universidade de São Paulo, Sao Paulo, Brazil, 2021.

80. Department for Education. School Food Standards Practical Guide. Available online: https://www.gov.uk/government/ publications/school-food-standards-resources-for-schools (accessed on 31 December 2021).

81. National Nutrition Concil. Eaten and Learning Together-School Meal Recommendation; National Nutrition Concil: Helsinki, Finland, 2017. 
82. Ajuntament de Barcelona. Declaració d' Emergència Climàtica; Ajuntament de Barcelona: Barcelona, Spain, 2020.

83. Consejo Interterritorial de Sistema Nacional de Salud. Documento de Consenso Sobre la Alimentacion en los Centros Educativos; Consejo Interterritorial de Sistema Nacional de Salud: Madrid, Spain, 2010.

84. The National Food Agency. National Guidelines for Meals at School. Preschool Class, Elementary School, High School and Leisure Center; The National Food Agency: Uppsala, Sweeden, 2021.

85. Senate Department for Education, Youth and Family. Reorganization of the School Lunch at Open and Affiliated All-Day Elementary Schools as Well as for Support Centers in the State of Berlin; Senate Department for Education, Youth and Family: Berlin, Germany, 2017; p. 28.

86. Brasil. Fundo Nacional de Desenvolvimento da Educação. Resolução no 06, de 08 de Maio de 2020. Dispõe sobre o Atendimento da Alimentação Escolar aos Alunos da Educação Básica no Âmbito do Programa Nacional de Alimentação Escolar—PNAE. 2020. Available online: https://www.fnde.gov.br/index.php/acesso-a-informacao/institucional/legislacao/item/13511-resolu\%C3 \%A7\%C3\%A3o-n\%C2\%BA-6,-de-08-de-maio-de-2020 (accessed on 31 December 2021).

87. Santa Catarina. Lei no 17504, de 10 de abril de 2018. Altera a ementa e o art. 1o, da Lei no 12.282, de 2002, que Dispõe Sobre o Fornecimento de Alimentos Orgânicos na Merenda Escolar nas Unidades Educacionais do Estado de Santa Catarina 2018. Available online: https://leisestaduais.com.br/sc/lei-ordinaria-n-17504-2018-santa-catarina-altera-a-ementa-e-o-art1o-da-lei-no-12-282-de-2002-que-dispoe-sobre-o-fornecimento-de-alimentos-organicos-na-merenda-escolar-nas-unidadeseducacionais-do-estado-de-santa-catarina (accessed on 31 December 2021).

88. E-Gov. Law Search. School Lunch Law. Available online: https://elaws.e-gov.go.jp/document?lawid=329AC0000000160 (accessed on 31 December 2021).

89. United States Department of Agriculture. Offer versus Serve Guidance for the National School Lunch Program and the School Breakfast Program. 2015. Available online: https://www.fns.usda.gov/cn/updated-offer-vs-serve-guidance-nslp-and-sbpbeginning-sy2015-16 (accessed on 31 December 2021).

90. California School Nutrition Association. 6 Principles of Behavioral Economics Used in Smarter Lunchrooms I Smarter Lunchrooms Movement. Available online: http://www.calsna.org/documents/events/2017Conference/Handouts/B6WasteNot.pdf (accessed on 24 November 2021).

91. National Farm to School Network. About Farm to School. Available online: https://www.farmtoschool.org/about/what-isfarm-to-school (accessed on 24 November 2021).

92. WFP. Home Grown School Feeding. Available online: https://www.wfp.org/home-grown-school-feeding (accessed on 24 November 2021).

93. Foundation for Environmental Education. Eco Schools. Available online: https://www.ecoschools.global/ (accessed on 2 December 2021).

94. Food for Life Partnership. Welcome to Food for Life. Available online: https://www.foodforlife.org.uk/ (accessed on 24 November 2021).

95. Willett, W.; Rockström, J.; Brent, L.; Springmann, M.; Lang, T.; Vermeulen, S.; Garnett, T.; Tilman, D.; DeClerck, F.; Wood, A.; et al. Food in the Anthropocene: The EAT-Lancet Commission on healthy diets from sustainable food systems. Lancet 2019, 393, 447-492. [CrossRef]

96. Hoover, A.; Vandyousefi, S.; Martin, B.; Nikah, K.; Cooper, M.H.; Muller, A.; Marty, E.; Duswalt-Epstein, M.; Burgermaster, M.; Waugh, L.; et al. Barriers, Strategies, and Resources to Thriving School Gardens. J. Nutr. Educ. Behav. 2021, 53, 591-601. [CrossRef]

97. Burt, K.G.; Luesse, H.B.; Rakoff, J.; Ventura, A.; Burgermaster, M. School Gardens in the United States: Current Barriers to Integration and Sustainability. Am. J. Public Health 2018, 108, 1543-1549. [CrossRef] [PubMed]

98. UN General Assembly. Transforming Our World: The 2030 Agenda for Sustainable Development. Available online: https: / / www.refworld.org/docid/57b6e3e44.html (accessed on 25 November 2021).

99. UNESCO. Learn for Our Planet: A Global Review of How Environmental Issues Are Integrated in Education; United Nations Educational, Scientific and Cultural Organization: Paris, France, 2021; p. 50.

100. Soil Association. Food for Life: Healthy, Local, Organic School Meals; Soil Association: Bristol, UK, 2003 ; p. 117.

101. Pancino, B.; Cicatiello, C.; Falasconi, L.; Boschini, M. School canteens and the food waste challenge: Which public initiatives can help? Waste Manag. Res. 2021, 39, 1090-1100. [CrossRef]

102. Derqui, B.; Fernandez, V.; Fayos, T. Towards more sustainable food systems. Addressing food waste at school canteens. Appetite 2018, 129, 1-11. [CrossRef] [PubMed]

103. García-Herrero, L.; De Menna, F.; Vittuari, M. Food waste at school. The environmental and cost impact of a canteen meal. Waste Manag. 2019, 100, 249-258. [CrossRef]

104. Liu, Y.; Cheng, S.; Liu, X.; Cao, X.; Xue, L.; Liu, G. Plate Waste in School Lunch Programs in Beijing, China. Sustainability 2016, 8, 1288. [CrossRef]

105. Palmer, S.; Herritt, C.; Cunningham-Sabo, L.; Stylianou, K.S.; Prescott, M.P. A Systems Examination of Food Packaging and Other Single-Use Item Waste in School Nutrition Programs. J. Nutr. Educ. Behav. 2021, 53, 380-388. [CrossRef]

106. González-García, S.; Esteve-Llorens, X.; González-García, R.; González, L.; Feijoo, G.; Moreira, M.T.; Leis, R. Environmental assessment of menus for toddlers serviced at nursery canteen following the Atlantic diet recommendations. Sci. Total Environ. 2021, 770, 145342. [CrossRef] 
107. Rodrigues, C.M.; Bastos, L.G.; Cantarelli, G.S.; Stedefeldt, E.; Cunha, D.T.; de Freitas Saccol, A.L. Sanitary, nutritional, and sustainable quality in food services of Brazilian early childhood education schools. Child. Youth Serv. Rev. 2020, 113, 104920. [CrossRef]

108. Maynard, D.D.C.; Zandonadi, R.P.; Nakano, E.Y.; Raposo, A.; Botelho, R.B.A. Green Restaurants ASSessment (GRASS): A Tool for Evaluation and Classification of Restaurants Considering Sustainability Indicators. Sustainability 2021, 13, 10928. [CrossRef]

109. Swinburn, B.A.; Kraak, V.I.; Allender, S.; Atkins, V.J.; Baker, P.I.; Bogard, J.R.; Brinsden, H.; Calvillo, A.; De Schutter, O.; Devarajan, R.; et al. The Global Syndemic of Obesity, Undernutrition, and Climate Change: The Lancet Commission report. Lancet 2019, 393, 791-846. [CrossRef]

110. Mekonnen, M.M.; Hoekstra, A.Y. A Global Assessment of the Water Footprint of Farm Animal Products. Ecosystems 2012, 15, 401-415. [CrossRef]

111. Food and Agriculture Organization of the United Nations. Food Wastage Footprint: Impacts on Natural Resources; Food and Agriculture Organization of the United Nations: Rome, Italy, 2013.

112. Lindgren, N. The political dimension of consuming animal products in education: An analysis of uppersecondary student responses when school lunch turns green and vegan. Environ. Educ. Res. 2020, 26, 684-700. [CrossRef]

113. Elinder, L.S.; Colombo, P.E.; Patterson, E.; Parlesak, A.; Lindroos, A.K. Successful Implementation of Climate-Friendly, Nutritious, and Acceptable School Meals in Practice: The OPTIMAT ${ }^{\mathrm{TM}}$ Intervention Study. Sustainability 2020, 12, 8475. [CrossRef]

114. Benvenuti, L.; De Santis, A.; Santesarti, F.; Tocca, L. An optimal plan for food consumption with minimal environmental impact: The case of school lunch menus. J. Clean. Prod. 2016, 129, 704-713. [CrossRef]

115. Ribal, J.; Fenollosa, M.L.; García-Segovia, P.; Clemente, G.; Escobar, N.; Sanjuán, N. Designing healthy, climate friendly and affordable school lunches. Int. J. Life Cycle Assess. 2016, 21, 631-645. [CrossRef]

116. Rossi, L.; Ferrari, M.; Martone, D.; Benvenuti, L.; De Santis, A. The Promotions of Sustainable Lunch Meals in School Feeding Programs: The Case of Italy. Nutrients 2021, 13, 1571. [CrossRef]

117. Bianchini, V.U. Critérios de Sustentabilidade para o Planejamento de Cardápios Escolares no Âmbito do Programa Nacional de Alimentação Escolar. Master's Thesis, Universidade Federal de Santa Catarina, Florianópolis, Brazil, 2017.

118. Morgan, K. Greening the Realm: Sustainable Food Chains and the Public Plate. Reg. Stud. 2008, 42, 1237-1250. [CrossRef]

119. Alexandre, V.P.; Gomes, L.O.F.; Silva, S.U.; Almeida, G.M.; Martins, K.A.; Monego, E.T.; Sousa, L.M.; Campos, M.R.H. Do campo à escola: Compra de alimentos da agricultura familiar pelo Programa Nacional de Alimentação Escolar em Territórios da Cidadania de Goiás. Segurança Aliment. Nutr. 2016, 23, 1049-1064. [CrossRef]

120. Amarante, E.A.L. Caracterização da Comercialização de Alimentos Através do Programa Nacional de Alimentação EscolarPNAE-no Município de Marechal Cândido Rondon-PR Como Estratégia para Promover a Sustentabilidade nos Empreendimentos da Agricultura Familiar. Undergraduate Thesis, Universisdade Estadual do Oeste do Paraná, Marechal Cândido Rondon, Brazil, 2016. Final paper.

121. Andreatta, T.; Martins, R.; Camara, S.B.; Gelatti, E. Efetividade do Programa Nacional de Alimentação Escolar sob a perspectiva dos agricultores familiares do município de Panambi-RS. Agric. Fam. Pesqui. Formação Desenvolv. 2021, 15, 135-155. [CrossRef]

122. Batlle-Bayer, L.; Bala, A.; Aldaco, R.; Vidal-Monés, B.; Colomé, R.; Fullana-I-Palmer, P. An explorative assessment of environmental and nutritional benefits of introducing low-carbon meals to Barcelona schools. Sci. Total Environ. 2021, 20, 143879. [CrossRef]

123. Braun, C.L.; Rombach, M.; Häring, A.M.; Bitsch, V. A Local Gap in Sustainable Food Procurement: Organic Vegetables in Berlin's School Meals. Sustainability 2018, 10, 4245. [CrossRef]

124. Breña, G.M. The Garden Talks: Cultivating Desire for Garden Education at Killip Elementary School. Master's Thesis, Northern Arizona University, Flagstaff, AZ, USA, 2017.

125. Carvalho, D.G. O Programa Nacional de Alimentação Escolar e a sustentabilidade: O caso do Distrito Federal. Master's Thesis, Universidade de Brasília, Brasília, Brazil, 2009.

126. Coleman, K.J.; Shordon, M.; Caparosa, S.L.; Pomichowski, M.E.; Pasadena, C.; Dzewaltowski, D.A.; Manhattan, K. Changing nutrition policies and environments in low-income schools using implementation models: The healthy options for nutrition environments in schools (ONES) intervention. In Obesity; Wiley Online Library: Hoboken, NJ, USA, 2012; Volume 19 , p. 124.

127. Colombo, P.E.; Patterson, E.; Lindroos, A.K.; Parlesak, A.; Elinder, L.S. Sustainable and acceptable school meals through optimization analysis: An intervention study. Nutr. J. 2020, 19, 61. [CrossRef]

128. Constanty, H.F.P.-H. Contribuições do PNAE na Sustentabilidade dos Agricultores Familiares: O Caso do Município de Marechal Cândido Rondon. Master's Thesis, Universidade Estadual do Oeste do Paraná, Marechal Cândido Rondon, Brazil, 2014.

129. Constanty, H.F.P.-H.; Zonin, W.J. Programa Nacional de Alimentação Escolar (PNAE) e sustentabilidade: O caso do município de Marechal Cândido Rondon. Desenvolv. Meio Ambient. 2016, 36, 371-392. [CrossRef]

130. Conner, D.S.; Abate, G.; Liquori, T.; Hamm, M.W.; Peterson, H.C. Prospects for more healthful, local, and sustainably produced food in school meals. J. Hunger Environ. Nutr. 2010, 5, 416-433. [CrossRef]

131. Damapong, S.N.; Kongnoo, W.; Monarumit, P. Lesson learned: Improvement of food quality in school and child development center for sustainable child nutrition. In Proceedings of the 20th International Congress of Nutrition, Granada, Spain, 15-20 September 2013; S. Karger AG: Basel, Switzerland, 2013; Volume 63, p. 1073.

132. Dirks, K.J. Sowing Seeds for Learning: A Case Study of a School Garden in Pocahontas, Iowa. Master's Thesis, Iowa State University, Ames, IA, USA, 2011. 
133. Eich, A.B. Percepções: Agricultura familiar e políticas públicas para alimentação escolar no município de São Paulo das MissõesRS. Direitos Sociais Politicas Públicas 2015, 3, 22-44.

134. Elnakib, S.A.; Quick, V.; Mendez, M.; Downs, S.; Wackowski, O.A.; Robson, M.G. Food Waste in Schools: A Pre-/Post-Test Study Design Examining the Impact of a Food Service Training Intervention to Reduce Food Waste. Int. J. Environ. Res. Public Health 2021, 18, 6389. [CrossRef]

135. Colombo, P.E. Optimizing school meals today: A pathway to sustainable dietary habits tomorrow. Ph.D. Thesis, Karolinska Institutet, Stockholm, Sweden, 2021.

136. Ferderbar, C.A. The Effects of In-Nature and Virtual-Nature Field Trip Experiences on Proenvironmental Attitudes and Behaviors, and Environmental Knowledge of Middle School Students. Ph.D. Thesis, Cardinal Stritch University, Glindale, CA, USA, 2013.

137. Filippini, R.; De Nonib, I.; Corsia, S.; Spigarolo, R.; Bocchi, S. Sustainable school food procurement: What factors do affect the introduction and the increase of organic food? Food Policy 2018, 76, 109-119. [CrossRef]

138. Fitzsimmons, J.; O'Hara, J.K. Market Channel Procurement Strategy and School Meal Costs in Farm-to-School Programs. Agric. Resour. Econ. Rev. 2019, 1-26. [CrossRef]

139. Franzoni, G.B. Inovação social e tecnologia social: O caso da cadeia curta de agricultores familiares e a alimentação escolar em Porto Alegre/RS. Master's Thesis, Universidade Federal do Rio Grande do Sul, Porto Alegre, Brazil, 2015.

140. Ghattas, H.; Choufani, J.; Jamaluddine, Z.; Masterson, A.R.; Sahyoun, N.R. Linking women-led community kitchens to school food programmes: Lessons learned from the Healthy Kitchens, Healthy Children intervention in Palestinian refugees in Lebanon. Public Health Nutr. 2020, 23, 914-923. [CrossRef]

141. Granillo-Macías, R. Logistics optimization through a social approach for food distribution. Socioecon. Plann. Sci. 2021, 76, 100972. [CrossRef]

142. Green, S. Using a Pen Pal Program to Assess Student Learning through Culture and School Gardens. Master's Thesis, Iowa State University, Ames, IA, USA, 2016.

143. Gregolin, G.C.; Gregolin, M.R.P.; Triches, R.M.; Zonin, W.J. Política pública e sustentabilidade: Possibilidade de interface no Programa Nacional de Alimentação Escolar-PNAE. Emancipação 2017, 17, 199-216.

144. He, C. Assessment of the impact of organic school meals to improve the school food environment and children's awareness of healthy eating habits. In Proceedings of the 20th International Congress of Nutrition, Granada, Spain, 15-20 September 2013; S. Karger AG: Basel, Switzerland, 2013; p. 840.

145. Hendler, V.M.; Ruiz, E.N.F.; Oliveira, L.D. de Sociobiodiversidade na escola, promoção da saúde, da sustentabilidade e da cultura: Um movimento em construção no município de Mostardas/RS. Agric. Fam. Pesqui. Formação Desenvolv. 2021, 15, 115-134.

146. Henry-Stone, L.R. Cultivating Sustainability through Participatory Action Research: Place-Based Education and Community Food Systems in Interior Alaska. Ph.D. Thesis, University of Alaska Fairbanks, Fairbanks, AK, USA, 2008.

147. Hodgkinson, T.M. Translating Sustainability: The Design of a Secondary Charter School. Ph.D. Thesis, The University of Iowa, Iowa City, IA, USA, 2011.

148. Johnston, Y.; Denniston, R.; Morgan, M.; Bordeau, M. Rock on Cafe: Achieving Sustainable Systems Changes in School Lunch Programs. Health Promot. Pract. 2009, 10, 100S-108S. [CrossRef] [PubMed]

149. Jones, P.K. The City Feeds the Poor: The Struggle for Sustainable Food Systems in San Francisco. Ph.D. Thesis, University of California, Santa Cruz, CA, USA, 2012.

150. Kipfer, H.J. Gaining Consensus on Implementation, Sustainability, and Benefits of School Garden Programming in Washington, D.C. Ph.D. Thesis, West Virginia University, Morgantown, WV, USA, 2018.

151. Koch, P.A. A comparison of two nutrition education curricula: Cookshops and food \& environment lessons. Ph.D. Thesis, Columbia University, New York, NY, USA, 2000.

152. Lalli, G.S. School meal time and social learning in England. Camb. J. Educ. 2020, 50, 57-75. [CrossRef]

153. Lauffer, B. Education for Sustainability: The Effectiveness of a Place Based Environmental Education Unit in Food Waste Reduction on the Environmental Awareness of Fourth Grade Students. Ph.D. Thesis, University of South Carolina, Columbia, SC, USA, 2019.

154. Lawless, T.H. Harnessing the Impact of Schools: New Insights for Sustainable Community Development. Ph.D. Thesis, Arizona State University, Tempe, AZ, USA, 2013.

155. Løes, A.-K.; Nölting, B. Organic school meal systems-towards a more sustainable nutrition. Agron. Res. $2009,7,647-653$.

156. McCarty, C.A. Alaskan Adolescent Nutrition Project. Master's Thesis, University of Alaska Anchorage, Anchorage, AK, USA, 2013.

157. Medina, J.L. A Dose-Response Analysis of a School-Based Nutrition Intervention in Middle School Children. Master's Thesis, University of Texas, Austin, TX, USA, 2009.

158. Melão, I.B. Produtos sustentáveis na alimentação escolar: O PNAE no Paraná. Cad. IPARDES Estud. Pesqui. 2012, 2, 87-105.

159. Mikkola, M. Role of Public Catering and Use of Organic Food in Educational Contexts: Creating Centres for Sustainable Food Systems; Bioforsk Organic Food and Farming: Tingvoll, Norway, 2010.

160. Moss Gamblin, M.K. (Kate) Becoming a Sustainability Chef: An Empirical Model of Sustainability Perspectives in Educational Leaders. Ph.D. Thesis, University of Toronto, Toronto, ON, Canada, 2013.

161. Mosimann, E.N. Agricultura familiar e alimentação escolar nas encostas da serra geral de Santa Catarina: Desafios e potencialidades. Master's Thesis, Universidade Federal de Santa Catarina, Florianópolis, Brazil, 2014. 
162. Morgan, K.J.; Morley, A. School Meals: Healthy Eating and Sustainable Food Chains; Regeneration Institute, Cardiff University: Cardiff, UK, 2003.

163. Mota, J.S.; Silva, D.W.; Pauletto, D. A inserção de produtos da Sociobiodiversidade na alimentação escolar no município de Santarém, PA. Agric. Fam. Pesqui. Formação Desenvolv. 2021, 15, 92-114. [CrossRef]

164. Muansrichai, S.; Panyasing, S.; Yonvanij, S. Learning and practicing in accordance with the sufficiency economy philosophy of third grade primary students in the local northeast socio-culural context of Thailand. Int. J. Appl. Bus. Econ. Res. 2015, 13, 4605-4619.

165. Nunes, E.M.; Morais, A.C.; Aquino, J.R.; Gurgel, I.A. O Programa Nacional de Alimentação Escolar (PNAE) como política de inclusão na agricultura familiar do Nordeste do Brasil. Rev. Grifos 2018, 45, 114-139. [CrossRef]

166. Nuutila, J.; Risku-Norja, H.; Arolaakso, A. Public kitchen menu substitutions increase organic share and school meal sustainability at equal cost. Org. Agric. 2019, 9, 117-126. [CrossRef]

167. Orr, E. Sustainable Waste Management in Schools. Master's Thesis, University of Rhode Island, Kingston, RI, USA, 2020.

168. Otsuki, K. Sustainable partnerships for a green economy: A case study of public procurement for home-grown school feeding. Nat. Resour. Forum 2011, 35, 213-222. [CrossRef]

169. Padilha, N.; Corbari, F.; Zanco, A.M.; Canquerino, Y.K.; Alves, A.F. The contribution of PNAE to sustainable rural development in the municipality of Pitanga-PR. Braz. J. Dev. 2018, 4, 4351-4365.

170. Osowski, C.P.; Fjellström, C. Understanding the ideology of the Swedish tax-paid school meal. Health Educ. J. 2019, 78, 388-398. [CrossRef]

171. Polo Galante, A.; Mireles, M.; Kiamba, J.; Mamadoultaibou, A.; Sablah, M.; Boitshepo, G.; Sanou, D. Innovative home grown school feeding linked to family farming: FAO school food and nutrition approach in sub-Saharan Africa. In Proceedings of the 21st International Congress of Nutrition, Buenos Aires, Argentina, 15-20 October 2017; Karger: Basel, Switzerland, 2017 ; p. 747.

172. Prescott, M.P.; Burg, X.; Metcalfe, J.J.; Lipka, A.E.; Herritt, C.; Cunningham-Sabo, L. Healthy Planet, Healthy Youth: A Food Systems Education and Promotion Intervention to Improve Adolescent Diet Quality and Reduce Food Waste. Nutrients 2019, 11, 1869. [CrossRef] [PubMed]

173. Rambing, D.R.; Wahyuni, C.U.; Isfandiardi, M.A.; Ssekalembe, G. Teachers' interpretation and behavior in conducting a Clean and Healthy Lifestyle Program at elementary schools in Kediri District. Eur. J. Mol. Clin. Med. 2020, 7, 3966-3976.

174. Redman, E. Development, Implementation, and Evaluation of Sustainability Education through the Integration of Behavioral Science into Pedagogy and Practice. Ph.D. Thesis, Arizona State University, Tempe, AZ, USA, 2013.

175. Resque, A.G.L.; Coudel, E.; Piketty, M.-G.; Cialdella, N.; Sá, T.; Piraux, M.; Assis, W.; Page, C. Le Agrobiodiversity and Public Food Procurement Programs in Brazil: Influence of Local Stakeholders in Configuring Green Mediated Markets. Sustainability 2019, 11, 1425. [CrossRef]

176. Ribeiro, A.L.d.P.; Ceratti, S.; Broch, D.T. Programa Nacional de Alimentação Escolar (PNAE) e a participação da agricultura familiar em municípios do Rio Grande do Sul. Rev. Gedecon. Rev. Gestão Desenvolv. Context 2013, 1. Available online: http:/ / revistaeletronica.unicruz.edu.br/index.php/GEDECON/article/view/282 (accessed on 7 December 2021).

177. Santos, F.; Fernandes, P.F.; Rockett, F.C.; de Oliveira, A.B.A. Evaluation of the inclusion of organic food from family-based agriculture in school food in municipalities of rural territories of the state of Rio Grande do Sul, Brazil. Cien. Saude Colet. 2014, 19, 1429-1436. [CrossRef]

178. Schachtner-Appel, A.E. Design, Implementation, and Evaluation of a Mindfulness Focused Nutrition Promotion Program to Balance USDA School Nutrition Goals with Food Waste Reduction in Elementary Schools. Ph.D. Thesis, University of Maryland, College Park, MD, USA, 2019.

179. Scott, R.A. The Nested Systems of Sustainability Education: Charting a Pathway to Ecological Learning. Master's Thesis, Prescott College, Prescott, AZ, USA, 2011.

180. Silva, A.P.F.; de Sousa, A.A. Organic foods from family farms in the National School Food Program in the State of Santa Catarina, Brazil. Rev. Nutr. 2013, 26, 701-714. [CrossRef]

181. Silva, A.B.; Pedon, N.R. Reprodução do campesinato através de políticas públicas voltadas para a agricultura familiar: A dinâmica do Programa Nacional de Alimentação Escolar (PNAE) em Ourinhos-SP. Rev. Nera 2015, 18, 92-109. [CrossRef]

182. Silva, D.W.; Gehlen, I.; Schultz, G. Family farm, public policies and citizenship: Connections built from the operation of the program national school feeding. Redes 2016, 21, 121-145. [CrossRef]

183. Silva, M.G.; Dias, M.M.; Amorim Junior, P.C.G. Mudanças Organizacionais em Empreendimentos de Agricultura Familiar a partir do Acesso ao Programa Nacional de Alimentação Escolar. Rev. Econ. Sociol. Rural 2015, 53, 289-304. [CrossRef]

184. Soares, P. Análise do programa de aquisição de alimentos na alimentação escolar em um município de Santa Catarina. Master's Thesis, Universidade Federal de Santa Catarina, Florianópolis, Brazil, 2011.

185. Soares, P.; Martinelli, S.S.; Melgarejo, L.; Cavalli, S.B.; Davó-Blanes, M.C. Using local family farm products for school feeding programmes: Effect on school menus. Br. Food J. 2017, 119, 1289-1300. [CrossRef]

186. Solof, L.E. Bay Area Student Involvement in the Environmental and Food Justice Movements: A Narrative of Motivations, Experiences, and Community Impact. Ph.D. Thesis, The University of San Francisco, San Francisco, CA, USA, 2014.

187. Sziwelski, N.K.; Teo, C.R.P.A.; Gallina, L.d.S.; Grahl, F.; Filippi, C. Programa Nacional de Alimentação Escolar (PNAE) [National School Feeding Program] implications in the income and organization of family farmers. Rev. Bras. Politicas Públicas 2015, 5, 220-239. 
188. Trott, C.D. Engaging Key Stakeholders in Climate Change: A Community-Based Project for Youth-Led Participatory Climate Action. Ph.D. Thesis, Colorado State University, Fort Collins, CO, USA, 2017.

189. Turpin, M.E. A Alimentação Escolar como Fator de Desenvolvimento Local por meio do Apoio aos Agricultores Familiares. Segur. Aliment. Nutr. 2009, 16, 20-42. [CrossRef]

190. Vasconcelos, M.G.; Vieira, S.S.; Rodrigues, V.W.B. Utilização de boas práticas de cultivo e manejo de hortaliças para uma alimentação escolar saudável. Rev. Extensão 2014, 13, 61-69. [CrossRef]

191. Valadão, W.B.; de Sousa, J.M.M. O PNAE em Viçosa-MG: Reflexões sobre a interface entre a produção e comercialização de alimentos advindos da agricultura familiar e a agroecologia. In Proceedings of the VI Congresso Latino-Americano de Agroecologia; X Congresso Brasileiro de Agroecologia; V Seminário de Agroecologia do Distrito Federal e Entorno, Brasília, Brazil, 12-15 September 2017; Cadernos de Agroecologia: Rio de Janeiro, Brazil, 2018.

192. Wade, S.A. Exploring the Influence of Agriculture Lessons on the Agricultural Knowledge and Beliefs of 4th Grade Students. Ph.D. Thesis, Grand Canyon University, Phoenix, AZ, USA, 2019.

193. Wickramasinghe, K.W.; Scarborough, P.; Townsend, N.; Goldacre, M.; Rayner, M. Estimating the changes in nutritional quality and environmental impact of primary school meals if all meals met the new school food plan standards in England. In Proceedings of the World Congress of Cardiology \& Cardiovascular Health, Mexico City, Mexico, 4-7 June 2016; Global Heart: Geneva, Switzerland, 2016; Volume 11, p. e128. 